Atmos. Chem. Phys., 20, 10029-10045, 2020

https://doi.org/10.5194/acp-20-10029-2020

(C) Author(s) 2020. This work is distributed under

the Creative Commons Attribution 4.0 License.

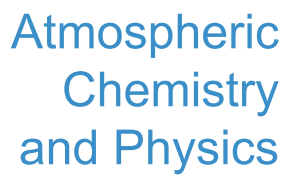

(c) (P)

\title{
Molecular insights into new particle formation in Barcelona, Spain
}

\author{
James Brean ${ }^{1}$, David C. S. Beddows ${ }^{1}$, Zongbo Shi ${ }^{1}$, Brice Temime-Roussel ${ }^{2}$, Nicolas Marchand ${ }^{2}$, Xavier Querol ${ }^{3}$, \\ Andrés Alastuey $^{3}$, María Cruz Minguillón ${ }^{3}$, and Roy M. Harrison ${ }^{1,4}$ \\ ${ }^{1}$ Division of Environmental Health and Risk Management, School of Geography, Earth and Environmental Sciences, \\ University of Birmingham, Edgbaston, Birmingham B15 2TT, UK \\ ${ }^{2}$ Aix Marseille Univ, CNRS, LCE, UMR 7376, 13331 Marseille, France \\ ${ }^{3}$ Institute of Environmental Assessment and Water Research (IDAEA-CSIC), Barcelona, 08034, Spain \\ ${ }^{4}$ Department of Environmental Sciences/Center of Excellence in Environmental Studies, King Abdulaziz University, \\ P.O. Box 80203, Jeddah, 21589, Saudi Arabia
}

Correspondence: Roy M. Harrison (r.m.harrison@bham.ac.uk)

Received: 28 January 2020 - Discussion started: 4 March 2020

Revised: 13 July 2020 - Accepted: 23 July 2020 - Published: 27 August 2020

\begin{abstract}
Atmospheric aerosols contribute some of the greatest uncertainties to estimates of global radiative forcing and have significant effects on human health. New particle formation (NPF) is the process by which new aerosols of sub- $2 \mathrm{~nm}$ diameter form from gas-phase precursors and contributes significantly to particle numbers in the atmosphere, accounting for approximately $50 \%$ of cloud condensation nuclei globally. Here, we study summertime NPF in urban Barcelona in north-eastern Spain utilising particle counting instruments down to $1.9 \mathrm{~nm}$ and a Nitrate Chemical Ionisation Atmospheric Pressure interface Time of Flight Mass Spectrometer (CI-APi-ToF). The rate of formation of new particles is seen to increase linearly with sulfuric acid concentration, although particle formation rates fall short of chamber studies of $\mathrm{H}_{2} \mathrm{SO}_{4}-\mathrm{DMA}-\mathrm{H}_{2} \mathrm{O}$ while exceeding those of $\mathrm{H}_{2} \mathrm{SO}_{4}-\mathrm{BioOxOrg}-\mathrm{H}_{2} \mathrm{O}$ nucleation, although a role of highly oxygenated molecules (HOMs) cannot be ruled out. The sulfuric acid dimer: monomer ratio is significantly lower than that seen in experiments involving sulfuric acid and dimethylamine (DMA) in chambers, indicating that stabilisation of sulfuric acid clusters by bases is weaker in this dataset than in chambers, either due to rapid evaporation due to high summertime temperatures or limited pools of stabilising amines. Such a mechanism cannot be verified in these data, as no higher-order $\mathrm{H}_{2} \mathrm{SO}_{4}$-amine clusters nor $\mathrm{H}_{2} \mathrm{SO}_{4}-\mathrm{HOM}$ clusters were measured. The high concentrations of HOMs arise from isoprene, alkylbenzene, monoterpene and polycyclic aromatic hydrocarbon (PAH) oxidation, with alkylbenzenes providing greater concentra-
\end{abstract}

tions of HOMs due to significant local sources. The concentration of these HOMs shows a dependence on temperature. The organic compounds measured primarily fall into the semivolatile organic compound (SVOC) volatility class arising from alkylbenzene and isoprene oxidation. Lowvolatility organic compounds (LVOCs) largely arise from oxidation of alkylbenzenes, PAHs and monoterpenes, whereas extremely low-volatility organic compounds (ELVOCs) arise from primarily PAH and monoterpene oxidation. New particle formation without growth past $10 \mathrm{~nm}$ is also observed, and on these days oxygenated organic concentrations are lower than on days with growth by a factor of 1.6, and thus high concentrations of low-volatility oxygenated organics which primarily derive from traffic-emitted volatile organic compounds (VOCs) appear to be a necessary condition for the growth of newly formed particles in Barcelona. These results are consistent with prior observations of new particle formation from sulfuric acid-amine reactions in both chambers and the real atmosphere and are likely representative of the urban background of many European Mediterranean cities. A role for HOMs in the nucleation process cannot be confirmed or ruled out, and there is strong circumstantial evidence of the participation of HOMs across multiple volatility classes in particle growth. 


\section{Introduction}

Atmospheric aerosols, defined as liquid or solid droplets suspended in a gas, affect the climate both directly by scattering and absorbing radiation and indirectly by acting as cloud condensation nuclei (CCN) (Penner et al., 2011), providing great uncertainties in estimates of global radiative forcing (IPCC, 2013). Further, fine ambient aerosols (defined as those with diameters below $2.5 \mu \mathrm{m}$ ) are the fifth greatest global mortality risk factor, resulting in 103.1 million disability-adjusted life years lost in 2015 (Cohen et al., 2017). The number concentration of the ultrafine fraction of these (aerosols with diameters below $0.1 \mu \mathrm{m}$, referred to as ultrafine particles or UFPs) pose potentially significant health risks also due to their high concentration and surface area. The more diffuse, gas-like behaviour of UFPs allows them to penetrate into the deep lung and enter the bloodstream (Miller et al., 2017). Ultrafine particles occur in the urban environment either as primary emissions (e.g. from car exhaust, Harrison et al., 2018) or secondarily as the product of new particle formation (NPF) (Brines et al., 2015; Guo et al., 2014; Kulmala et al., 2017; Lee et al., 2019).

NPF is the formation of aerosol particles from gas-phase precursors. NPF can be considered a two-step process involving initial formation of a cluster of gas molecules at the critical diameter at around $1.5 \mathrm{~nm}$ - the diameter at which a free-energy barrier must be overcome to allow the spontaneous phase transition from gas to liquid or solid (Zhang et al., 2012) - and the subsequent growth of this droplet to a larger aerosol particle. The first step of this process is dependent upon the stability and abundance of the clustering molecules. Sulfuric acid, water, and dimethylamine (DMA), for example, efficiently form particles as the strong hydrogen bonding between the acid-base pair produces near-negligible evaporation, much lower than the evaporation rate seen for the more weakly bound sulfuric acid-ammonia-water system. Nucleation of sulfuric acid, DMA and water proceeds at or near to the kinetic limit in a chamber at $278 \mathrm{~K}$ when DMA mixing ratios are sufficient (Almeida et al., 2013; Kürten et al., 2014). Once past this $1.5 \mathrm{~nm}$ diameter, condensation and coagulation will drive particle growth. Both the abundance of condensable gases and their vapour pressures limit condensational growth. Vapour pressures are especially important for the initial growth stages, as the Kelvin effect barrier impairs condensation of more volatile species, with this condition of low vapour pressures becoming less significant as the diameter of the particle increases (Tröstl et al., 2016). Once sufficiently large $(>50 \mathrm{~nm})$, the loss processes of coagulation and evaporation of these particles become inefficient, resulting in a significant atmospheric lifetime. It is from these diameters onwards that the climate forcing effects of these particles become most pronounced.

NPF processes happen globally, across a diverse range of environments from pristine polar regions to polluted urban megacities (Kerminen et al., 2018), and represent a signifi- cant source of CCN, with $10 \%-60 \%$ of NPF events shown to produce $\mathrm{CCN}$ and enhancement factors to $\mathrm{CCN}$ count ranging from 0.5 to 11 (Lee et al., 2019, and references within). Strong NPF events are observed across a range of urban environments, despite high condensation sinks $>10^{-2} \mathrm{~s}^{-1}$ (Bousiotis et al., 2019; Yu et al., 2016), and can act as a precursor to strong haze events (Guo et al., 2014). The occurrence of urban NPF has only been partially explained by growing understanding from recent in-depth studies (Yao et al., 2018). Recent advances in instrumentation allow for the measurement of particles down to the critical diameter with instruments such as the particle size magnifier (PSM) and (Neutral) Air Ion Spectrometer (NAIS/AIS) (Lee et al., 2019) and mass spectral techniques for measuring the abundance and composition of neutral (Jokinen et al., 2012) and charged (Junninen et al., 2010) clusters. Elucidated mechanisms with these techniques involve sulfuric acid and ammonia in remote environments (Jokinen et al., 2018; Yan et al., 2018), monoterpene-derived highly oxygenated molecules (HOM) in remote environments (Rose et al., 2018), iodic acid in coastal environments (Sipilä et al., 2016), and sulfuric acid and DMA in polluted urban environments (Yao et al., 2018).

Urban Barcelona sees frequent, strong summer-time NPF events occurring on $28 \%$ of days. These events are associated with high insolation and elevated ozone $\left(\sim 60 \mu \mathrm{g} \mathrm{m}^{-3}\right)$ when considering the whole year (Brines et al., 2014, 2015). Ground-level observations report NPF events starting typically at midday and either occurring in urban Barcelona and the surrounding regional background simultaneously or isolated to either urban Barcelona or just the regional background (Dall'Osto et al., 2013). Vertical profiles over urban Barcelona reveal that NPF occurs at higher altitudes and starts earlier in the day, as at a given altitude these events are not suppressed by early traffic peaks contributing to particle load (Minguillón et al., 2015). Here, we examine gas-phase mass spectral evidence and particle formation rates at the critical diameter from sulfuric acid in Barcelona, with possible contribution from strong bases and highly oxygenated organic molecules (HOMs), as well as factors influencing subsequent particle growth.

\section{Methods}

\subsection{Sampling site}

The Palau Reial site in Barcelona $\left(41^{\circ} 23^{\prime} 15^{\prime \prime} \mathrm{N}\right.$, $\left.2^{\circ} 6^{\prime} 53.64^{\prime \prime} \mathrm{E}\right)$ is representative of the urban background of Barcelona, located at the Institute of Environmental Assessment and Water Research (IDAEA-CSIC) in the north-west of the city. Sampling was performed from a container $20 \mathrm{~m}$ from a low traffic road and $200 \mathrm{~m}$ from the nearest main road (Avinguda Diagonal). Data were taken from 28 June through 18 July 2018. 


\subsection{Chemical Ionisation Atmospheric Pressure interface Time of Flight Mass Spectrometer}

The Aerodyne Nitrate Chemical Ionisation Atmospheric Pressure interface Time of Flight Mass Spectrometer (CIAPi-ToF) was used to make measurements of neutral oxygenated organic compounds, organic and inorganic acids, bases, and their molecular clusters at high time resolution with high resolving power. The ionisation system charges molecules by adduct formation, such as in the case of organic compounds with two or more hydrogen bond donor groups (Hyttinen et al., 2015) or proton transfer in the case of strong acids like sulfuric acid (Jokinen et al., 2012). Hydroxyl or hydroperoxyl functionalities are both common hydrogen bond donating groups, with hydroperoxyl being the more efficient hydrogen bond donor (Møller et al., 2017). This instrument has been explained in great detail elsewhere (Jokinen et al., 2012; Junninen et al., 2010), but briefly, the front end consists of a chemical ionisation system where a $10 \mathrm{~L} \mathrm{~min}^{-1}$ sample flow is drawn in through the $1 \mathrm{~m}$ length $1^{\prime \prime}$ OD stainless steel tubing opening. A secondary flow was run parallel and concentric to this sample flow, rendering the reaction chamber effectively wall-less. A $3 \mathrm{~cm}^{3} \mathrm{~min}^{-1}$ flow of a carrier gas $\left(\mathrm{N}_{2}\right)$ is passed over a reservoir of liquid $\mathrm{HNO}_{3}$, entraining vapour which is subsequently ionised to $\mathrm{NO}_{3}^{-}$via an $\mathrm{X}$-ray source. Ions are then guided into the sample flow. The nitrate ions will then charge molecules either by clustering or proton transfer. The mixed flows travelling at $10 \mathrm{~L} \mathrm{~min}^{-1}$ enter the critical orifice at the front end of the instrument at $0.8 \mathrm{~L} \mathrm{~min}^{-1}$ and are guided through a series of differentially pumped chambers before reaching the ToF analyser. All data analysis was carried out in the Tofware package in Igor Pro 7 (Tofwerk AG, Switzerland). Signals except for those of amines and ammonia are divided by the sum of reagent ion signals and multiplied by a calibration coefficient to produce a concentration. A calibration coefficient of $3 \times 10^{9} \mathrm{~cm}^{-3}$ was established based upon comparison with a sulfuric acid proxy (Mikkonen et al., 2011) and is in line with a prior calibration with our instrument (Brean et al., 2019). Uniform sensitivity between $\mathrm{H}_{2} \mathrm{SO}_{4}$ and all other species measured by $\mathrm{CI}-\mathrm{APi}-\mathrm{ToF}$ bar amines and ammonia was assumed in this work. This introduces some uncertainties, as it relies upon both collision rates and charging efficiencies to be the same within the ionisation source for all species. Amine and ammonia signals are normalised to the nitrate trimer signal (Simon et al., 2016). Prior reports of ammonia and amines as measured by CI-APi-ToF employed corona discharge systems, which utilise higher concentrations of nitric acid, and thus we report normalised signals. We present correlations of each of these bases clustered with the nitrate dimer plotted against measurements with the nitrate trimer as well as their intercorrelations and example peak fits across Fig. $\mathrm{S} 1$ in the Supplement. $\mathrm{C}_{2}$ amines, $\mathrm{C}_{4}$ amines and ammonia were the only molecules of this kind found in our mass spectra. Systematic uncertainties of $+100 \% /-50 \%$ arising from this method are assumed.

Due to the high resolving power of the CI-APi-ToF system (mass resolving power of 3000 and mass accuracy of $20 \mathrm{ppm}$ at $201 \mathrm{~m} \mathrm{Q}^{-1}$ ), multiple peaks can be fitted at the same unit mass and their molecular formulae assigned. Beyond $500 \mathrm{~m} \mathrm{Q}^{-1}$, peak fitting and assignment of compositions become problematic as the signal decreases, mass accuracy decreases, and the total number of possible chemical compositions increases, so peaks above the $\mathrm{C}_{20}$ region have not been assigned (Cubison and Jimenez, 2015); however, signals past this region tended to be extremely low. All ions identified are listed in Table S1 in the Supplement. As proton transfer mostly happens with acids and nearly all HOM molecules will be charged by adduct formation, it is possible to infer the uncharged formula; therefore, all HOMs from here onwards will be listed in their uncharged form. The CI-APi-ToF inlet was placed approximately $1.5 \mathrm{~m}$ a.g.l. CI-APi-ToF data are only available between the dates 6 and 17 July 2018.

\subsection{Particle size and number measurements}

Two Scanning Mobility Particle Sizer (SMPS) instruments measured particle size distributions at $5 \mathrm{~min}$ time resolution, one Long Column SMPS (TSI 3080 EC, 3082 Long DMA, 3772 CPC, TSI, USA) and one NanoSMPS (3082 EC, 3082 Nano DMA, 3776 CPC, TSI, USA) measuring the ranges $10.9-478.3 \mathrm{~nm}$ and $4.5-65.3 \mathrm{~nm}$ respectively. A Particle Size Magnifier (A10, Airmodus, FN) linked to a CPC (3775, TSI, USA) measured the sub- $3 \mathrm{~nm}$ size fraction. The PSM was run in stepping mode, operating at four different saturator flows to vary the lower size cut of particles that it will grow (defined as the point of $50 \%$ efficiency, $D_{50}$ ). The instrument provided $D_{50}$ from 1.4 to $2.4 \mathrm{~nm}$. The instrument switched between saturator flows each $2.5 \mathrm{~min}$, giving a sub- $2.4 \mathrm{~nm}$ size distribution every $10 \mathrm{~min}$. Aerosol sampling inlets were placed approximately $2 \mathrm{~m}$ a.g.l.

\subsection{Other measurements}

Mixing ratios of non-methane volatile organic compounds (VOCs) with proton affinity greater than $\mathrm{H}_{3} \mathrm{O}^{+}$were made using the proton transfer reaction time of flight mass spectrometer (PTR-ToF-MS 8000, Ionicon Analytik GmbH, Austria). A detailed description of the instrument is provided by Graus et al. (2010). The sampling setup, operating conditions, and quantification procedures are similar to those described in Minguillón et al. (2016). Continual monitoring of the composition and mass of submicron aerosol $>75 \mathrm{~nm}$ was carried out with an Aerosol Chemical Speciation Monitor (ACSM, Aerodyne, USA) (Ng et al., 2011). Ozone, NO, and $\mathrm{NO}_{2}$ were measured by conventional ultraviolet and chemiluminiscence air quality instrumentation. Meteorological data were supplied by the Faculty of Physics of the University of 
Barcelona from a nearby ( $200 \mathrm{~m}$ from the measurement site) meteorological station located at the roof of an eight-floor building.

\subsection{Condensation sink and particle growth rate}

The condensation sink (CS) represents the rate at which a vapour-phase molecule will collide with a pre-existing particle surface and was calculated from the size distribution data as follows (Kulmala et al., 2012):

$\mathrm{CS}=2 \pi D \sum_{d_{\mathrm{p}}} \beta_{m, d_{\mathrm{p}}} d_{\mathrm{p}} N_{d_{\mathrm{p}}}$,

where $D$ is the diffusion coefficient of the diffusing vapour (assumed to be sulfuric acid), $\beta_{m}$ is a transition regime correction (Kulmala et al., 2001), $d_{\mathrm{p}}$ is the particle diameter, and $N_{d_{\mathrm{p}}}$ is the number of particles at diameter $d_{\mathrm{p}}$. The formation rate of new particles at size $d_{\mathrm{p}}$ is calculated as follows:

$J_{d_{\mathrm{p}}}=\frac{\mathrm{d} N_{d_{\mathrm{p}}}}{\mathrm{d} t}+\operatorname{Coag} S_{d_{\mathrm{p}}} \cdot N_{d_{\mathrm{p}}}+\frac{\mathrm{GR}}{\Delta d_{\mathrm{p}}} N_{d_{\mathrm{p}}}$,

where the first term on the right-hand side comprises the rate at which particles enter the size $d_{\mathrm{p}}$, and the latter two terms represent losses from this size by coagulation and growth respectively. $J_{5}$ was calculated using the data in the range of $5-10 \mathrm{~nm}$, and $J_{1.9}$ was calculated using the measurements in the range of $1.9-4.5 \mathrm{~nm}$. We also calculated $J_{1.9}$ from our NanoSMPS data, employing the equations of Lehtinen et al. (2007). $J_{1.9}$ from both methods showed reasonable agreement $\left(R^{2}=0.34\right)$. Agreement between $J_{5}$ and $J_{1.9}$ for each method was similar $\left(R^{2}=0.37\right.$ and $R^{2}=0.38$ for $J_{1.9}$ calculated from PSM data and from Lehtinen et al., 2007, respectively). $J_{1.9}$ is greater than $J_{5}$ as predicted from Eq. (2) by around a factor of 20. See Kulmala et al. (2001) for more information on calculation of coagulation sinks and formation rates. Growth rates (GRs) in the range of $4.5-20 \mathrm{~nm}$ were calculated according to the lognormal distribution function method (Kulmala et al., 2012), whereas those in the range of 1.9-4.5 nm were calculated from PSM data using a timedelay method between PSM and NanoSMPS data. Systematic uncertainties in our calculated $J_{1.9}$ values include $25 \%$ method uncertainty (Yli-Juuti et al., 2017), with a further $25 \%$ arising from uncertainties in PSM cutoff $( \pm 0.5 \mathrm{~nm})$ as well as a $10 \%$ uncertainty in counting errors. A $50 \%$ error arising from calculated coagulation sink is also applied (Kürten et al., 2016). The above calculations rely on the assumption of homogeneous air masses, and while air mass advection as well as primary particle emissions can cause errors in estimations of temporal changes in particle count and diameter, the appearance and persistence of a new mode of particles across a period of several hours are typically indicative of a regional process.

Growth rates from irreversible condensation of various vapours were calculated as according to Nieminen et al. (2010). At our measured relative humidity, sulfuric acid favours binding to two $\mathrm{H}_{2} \mathrm{O}$ molecules (Kurtén et al., 2007). As amine concentrations are likely limited, we presume no mass from amines in the condensing species. $\mathrm{H}_{2} \mathrm{SO}_{4}$ was assigned a density of $1.8 \mathrm{~g} \mathrm{~cm}^{-3}$. For simplicity, the properties of methanesulfonic acid (MSA) regarding density and hydration were presumed to be the same as $\mathrm{H}_{2} \mathrm{SO}_{4}$, and $\mathrm{HIO}_{3}$ was presumed to have the same hydration as $\mathrm{H}_{2} \mathrm{SO}_{4}$, with a density of $4.98 \mathrm{~g} \mathrm{~cm}^{-3}$. The density of condensing organic vapours was assumed to be $1.5 \mathrm{~g} \mathrm{~cm}^{-3}$, and concentrationweighted mean mass $\left(\sim 276 \mathrm{~g} \mathrm{~mol}^{-1}\right.$ for low-volatility organic compounds - LVOCs) and atomic-weighted diffusion volumes of organic compounds were used to calculate GRs.

\subsection{DBE and 2D-VBS}

The double-bond equivalent (DBE) describes the degree of unsaturation of an organic molecule and is defined simply as

$\mathrm{DBE}=N_{\mathrm{C}}-\frac{N_{\mathrm{H}}}{2}-\frac{N_{\mathrm{N}}}{2}+1$.

The saturation vapour pressure at $300 \mathrm{~K}$ is defined by the $2 \mathrm{D}$ volatility basis set (2D-VBS) as follows, if all nitrogen functionality is assumed to take the form $-\mathrm{ONO}_{2}$ (Bianchi, 2019; Donahue, 2011; Schervish and Donahue, 2020):

$$
\begin{aligned}
\log _{10}\left(C^{*}\right)(300 \mathrm{~K}) & =\left(N_{\mathrm{C} 0}-N_{\mathrm{C}}\right) b_{\mathrm{C}}-N_{\mathrm{O}} b_{\mathrm{O}} \\
& -2 \frac{N_{\mathrm{O}} N_{\mathrm{C}}}{N_{\mathrm{C}}+N_{\mathrm{O}}} b_{\mathrm{CO}}-N_{\mathrm{N}} b_{\mathrm{N}},
\end{aligned}
$$

where $N_{\mathrm{C}}, N_{\mathrm{H}}$, and $N_{\mathrm{N}}$ are the number of carbon, hydrogen, and nitrogen atoms respectively. $N_{\mathrm{O}}$ is the number of oxygen atoms minus $3 N_{\mathrm{N}}$ to account for - $\mathrm{ONO}_{2}$ groups, $N_{\mathrm{C} 0}$ is 25 (the carbon number of an alkane with a saturation mass concentration of $1 \mu \mathrm{g} \mathrm{m}^{-3}$ ), and $b_{\mathrm{C}}, b_{\mathrm{O}}, b_{\mathrm{CO}}$, and $b_{\mathrm{N}}$ are 0.475 , $0.2,0.9$ and 2.5 respectively and represent interaction and nonideality terms. The final term of Eq. (4) accounts for $\mathrm{ONO}_{2}$ groups, each reducing the saturation vapour pressure by 2.5 orders of magnitude. $C^{*}$ values are calculated at $300 \mathrm{~K}$ and not corrected for temperature, as $300 \mathrm{~K}$ is within $1 \mathrm{~K}$ of the campaign average temperature.

\section{Results and discussion}

\subsection{General conditions of NPF events}

Summer NPF events in the regional background around Barcelona are associated with high insolation, relatively low ozone concentration (high compared with the rest of the year), and lower particulate matter load (Brines et al., 2014; Carnerero et al., 2019). Figure 1 shows an example of a day with no NPF in panel (a), referred to as "nonevent" here, where two traffic-associated peaks in particle number are seen during rush hours. Midday traffic peaks 
are also seen on certain days, but these are easily distinguished from nucleation processes due to the lack of a significant $<10 \mathrm{~nm}$ mode. Figure $1 \mathrm{~b}$ shows a nucleation day with growth to larger sizes $>10 \mathrm{~nm}$, termed "full-event", showing the growth through the course of the day. These fulfil all the criteria of Dal Maso et al. (2005). Four events of this type were observed with CI-APi-ToF data coverage. Figure 1c shows a day with nucleation occurring but no growth past $10 \mathrm{~nm}$. These days are referred to as "burstevent" days. Here, NPF is seen to occur, but particles fail to grow past the nucleation mode. Two such events were seen in these data with CI-APi-ToF data coverage, and both are accompanied by a distinct mode appearing beforehand in the range of $\sim 20-40 \mathrm{~nm}$. Condensation sinks were not significantly higher than on full-event days, so this failure of particles to grow further cannot be attributed to condensational (or coagulational) losses. GR $4.5-20$ ranged between 2.47 and $7.31 \mathrm{~nm} \mathrm{~h}^{-1}\left(4.69 \pm 2.03 \mathrm{~nm} \mathrm{~h}^{-1}\right)$ and $\mathrm{GR}_{1.9-4.5}$ ranged between 3.12 and $5.20 \mathrm{~nm} \mathrm{~h}^{-1}\left(4.36 \pm 1.02 \mathrm{~nm} \mathrm{~h}^{-1}\right)$. The survival parameter $(P)$ as suggested by Kulmala et al. (2017) is defined as $\mathrm{CS} \times 10^{-4} / \mathrm{GR}$, and for these data it is equal to 41, higher than other European cities.

Figure 2 contains box plots showing condensation sink, temperature and global radiation for all three NPF types across the entire day (diurnal profiles plotted in Fig. S2). Condensation sinks during NPF periods of both types (Fig. 1b and c) were not significantly lower than in nonevent periods. Condensation sinks were suppressed prior to the beginning of an event for full events, increasing relative to non-events through the afternoon period. Of the two burst events, one was similarly characterised by a suppression to the condensation sink, whereas the other showed a sharp rise in the midday. Global radiation and temperature were higher for full events, most significantly for temperature. Figure 3 is as Fig. 2 but for sulfuric acid, ammonia and amines, and HOMs as measured by CI-APi-ToF (HOM criteria are discussed in Sect. 3.3.1). Sulfuric acid is elevated during both full-event and burst-event periods. In urban Barcelona, sulfuric acid will primarily arise from oxidation of $\mathrm{SO}_{2}$ by the $\mathrm{OH}^{*}$ radical, with anthropogenic emissions such as shipping emissions from the port areas being significant sources of $\mathrm{SO}_{2}$ (Henschel et al., 2013). Direct traffic emissions have been shown to be a significant primary sulfuric acid source (Olin et al., 2020), but our sulfuric acid data show no traffic peaks. Ammonia and amines show enhancement for fullevent periods but not burst-event periods. Nucleation rates (at typical tropospheric sulfuric acid concentrations) are sensitive to amine concentrations in the range of a few pptv, with enhancements to amine mixing ratios past this point increasing the nucleation rate marginally (Almeida et al., 2013), while typical concentrations of DMA and other alkylamines vary from zero to a few pptv in the boundary layer (Ge et al., 2011a).

Barcelona has been shown to contain ppbv levels of ammonia (Pandolfi et al., 2012) arising from both agriculture to the north (Van Damme et al., 2018) and anthropogenic activities such as waste management and traffic, with waste management being the primary ammonia source. The highest ammonia mixing ratios are found in the densely populated old city centre (Reche et al., 2015). Agriculture, waste management, and traffic are also all significant sources of low molecular weight alkylamines, such as DMA (Ábalos et al., 1999; Cadle and Mulawa, 1980; Hutchinson et al., 1982; Ge et al., 2011a), and are likely the source of amines found in this dataset. Activities such as composting and food industry are especially strong sources of trimethylamine (TMA) (Ge et al., 2011a). Although high emission fluxes of TMA are expected in this environment, they are not present in our spectra. The TMA ion has been reported previously with a similar ionisation setup to that utilised in this study (Kürten et al., 2016). On full-event days, the signal for $C_{2}$ and $C_{4}$ amines has a midday elevation concurrent with peaks to solar radiation (Fig. S2) and can help explain the high formation rates we see in this dataset (see Sect. 3.2). The relative strengths of these signals are shown in Fig. S3, with significantly higher signals attributed to ammonia compared to amines, despite a likely lower sensitivity (Simon et al., 2016).

HOM concentrations were greatly enhanced during fullevent periods (factor of 1.5 higher compared to non-NPF mean) but lower during burst-event periods (factor of 1.2 lower compared to non-NPF mean), implying their necessity for growth. The sources and implications of these HOMs are discussed in Sect. 3.3. Further, concentrations of iodine and DMS-derived acids such as iodic acid $\left(\mathrm{HIO}_{3}\right)$ and MSA are low $\left(7.8 \times 10^{5}\right.$ and $3.3 \times 10^{5} \mathrm{~cm}^{-3}$ respectively), indicating a small influence of oceanic emissions on particle nucleation/growth. Extended box plots as Figs. 2 and 3 are presented in Fig. S4 and HYSPLIT back trajectories per event in Fig. S5.

\subsection{Mechanisms of new particle formation}

The correlation between $J_{1.9}$ and concentration of sulfuric acid is plotted in Fig. 4. A close relationship between nucleation rates and sulfuric acid concentrations $\left(R^{2}=0.49\right)$ is consistent with observations globally (Lee et al., 2019). This relationship is not dependent upon the condensation sink. These NPF rates have no dependence on other ions as measured by $\mathrm{CI}-\mathrm{APi}-\mathrm{ToF}$, including $\mathrm{HIO}_{3}$, MSA, ammonia, amines or HOMs $\left(R^{2}\right.$ for all $\left.<0.1\right)$. This is not to say that all of these molecules are not involved in the nucleation process, rather that elevations or reductions to their concentrations during nucleation periods do not have a significant impact on nucleation rates. In the example of alkylamines, their gas-phase concentration may decrease due to clustering with elevated sulfuric acid, as they cluster at around a $1: 1$ ratio at high amine mixing ratios (Kürten et al., 2014) (and therefore they will not be detectable as free amines). Further, if amines are present at a few pptv, their mixing ratios are significantly higher than our ambient measured sulfuric acid 
(a)

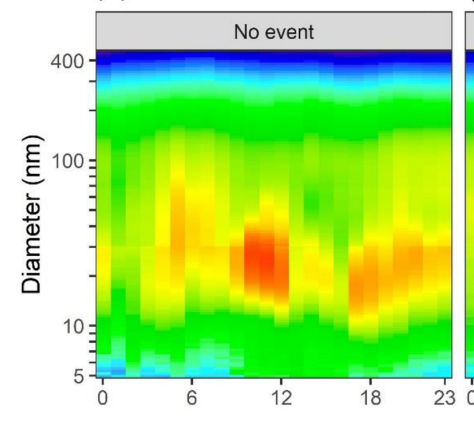

$\mathrm{dN} / \operatorname{dlog} \mathrm{D}_{\mathrm{p}}\left(\mathrm{cm}^{-3}\right) \frac{1}{100 \quad 1000} 10000$

(b)

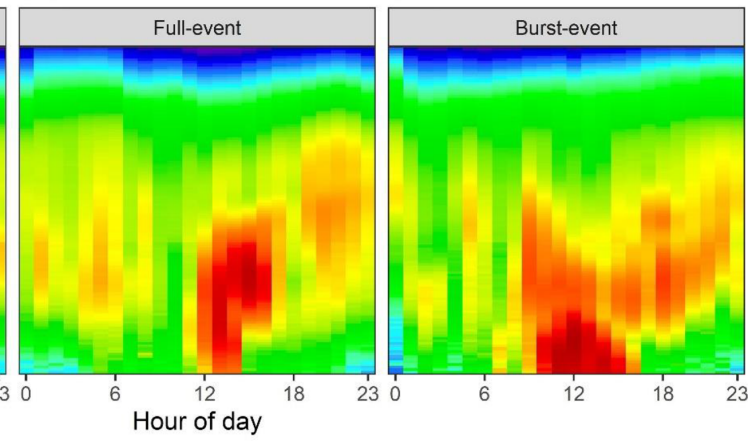

Figure 1. Average SMPS contour plots for (a) non-event days, (b) full-event days and (c) burst-event days.

(a)

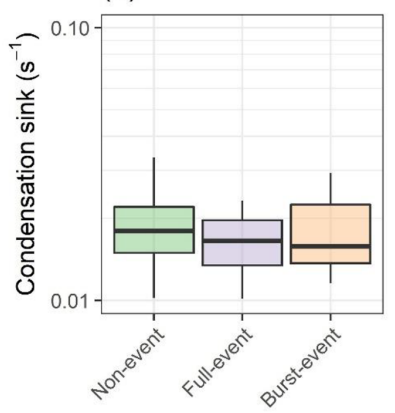

(b)

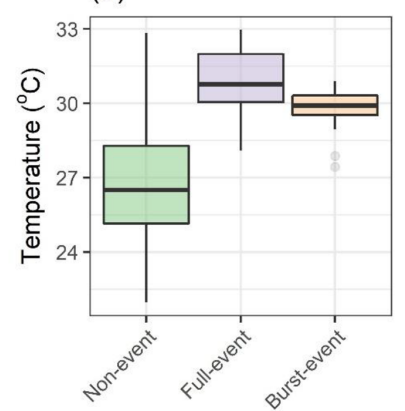

(c)

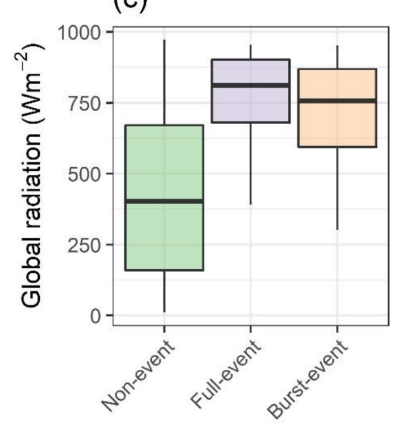

Figure 2. Box plots for days of non-event, full-event and burst-event, showing (a) condensation sink, (b) temperature, and (c) global radiation from hourly data. "Full-event" and "burst-event" include data across the entire day.

concentrations and will be sufficient to accelerate nucleation rates (Almeida et al., 2013). Photochemical losses will also be greater during the periods of the highest NPF rate (Ge et al., 2011b). The strength of the relationship between sulfuric acid and nucleation rate has been quantitatively reproduced in chamber studies involving the $\mathrm{H}_{2} \mathrm{SO}_{4}-\mathrm{H}_{2} \mathrm{O}-\mathrm{DMA}$ and the $\mathrm{H}_{2} \mathrm{SO}_{4}-\mathrm{H}_{2} \mathrm{O}-\mathrm{BioOxOrg}$ system, accurately reproducing tropospheric observations of nucleation rates (Almeida et al., 2013; Riccobono et al., 2014), although a later revision of the former shows nucleation rates at $278 \mathrm{~K}$ exceeding typical tropospheric observations in the presence of high mixing ratios of DMA (Kürten et al., 2018). A comparison between our data and results from the CLOUD chamber is presented in Fig. 5; included are the $\mathrm{H}_{2} \mathrm{SO}_{4}-\mathrm{H}_{2} \mathrm{O}, \mathrm{H}_{2} \mathrm{SO}_{4}-\mathrm{NH}_{3}-\mathrm{H}_{2} \mathrm{O}$ (Kirkby et al., 2011), $\mathrm{H}_{2} \mathrm{SO}_{4}-\mathrm{H}_{2} \mathrm{O}-\mathrm{DMA}$ (Kürten et al., 2018) and $\mathrm{H}_{2} \mathrm{SO}_{4}-\mathrm{BioOxOrg}-\mathrm{H}_{2} \mathrm{O}$ systems (Riccobono et al., 2014) - BioOxOrg refers to the oxidation products of pinanediol $\left(\mathrm{C}_{10} \mathrm{H}_{18} \mathrm{O}_{2}\right)$ and $\mathrm{OH}^{\circ}$. Data from these chamber experiments are for $278 \mathrm{~K}$ and $38 \%-39 \%$ relative humidity. Nucleation rates measured in Barcelona $\left(J_{1.9} 178 \pm\right.$ $190 \mathrm{~cm}^{-3} \mathrm{~s}^{-1}$ at $\left[\mathrm{H}_{2} \mathrm{SO}_{4}\right] 7.1 \times 10^{6} \pm 2.7 \times 10^{6} \mathrm{~cm}^{-3}$ ) are around an order of magnitude lower than that seen for the $\mathrm{H}_{2} \mathrm{SO}_{4}-\mathrm{DMA}-\mathrm{H}_{2} \mathrm{SO}_{4}$ system but exceed that of the $\mathrm{H}_{2} \mathrm{SO}_{4}-$
BioOxOrg $-\mathrm{H}_{2} \mathrm{O}$ system by $\sim 1$ order of magnitude and that of the $\mathrm{H}_{2} \mathrm{SO}_{4}-\mathrm{NH}_{3}-\mathrm{H}_{2} \mathrm{O}$ and $\mathrm{H}_{2} \mathrm{SO}_{4}-\mathrm{H}_{2} \mathrm{O}$ systems by multiple orders of magnitude. No dissimilarity is seen between the data points corresponding to full or burst-type nucleation, indicating similar mechanisms of formation despite lower HOM concentrations on burst-event days. Conversely, research in remote boreal environments shows that the mechanism of nucleation can modulate dependent upon the $\mathrm{H}_{2} \mathrm{SO}_{4}$ : HOM ratio (Yan et al., 2018). Model studies of sulfuric acid-amine nucleation show a decline in nucleation rate with an increasing temperature (Almeida et al., 2013; Olenius et al., 2017), as the evaporation rate of sulfuric acid-amine clusters will increase with temperature (Paasonen et al., 2012). Conversely, evaporation rates of such small clusters and resultant nucleation rates tend to increase modestly, with increases in relative humidity most pronounced at lower amine concentrations (Almeida et al., 2013; Paasonen et al., 2012). Despite this, high nucleation rates at temperatures nearing $300 \mathrm{~K}$ have been reported previously (Kuang et al., 2008; Kürten et al., 2016), although these tend to show a temperature dependence (Yu et al., 2016). No higher-order sulfuric acid clusters, sulfuric acid-base clusters, or sulfuric acid-HOM clusters were visible in the mass spectral data, 
(a)

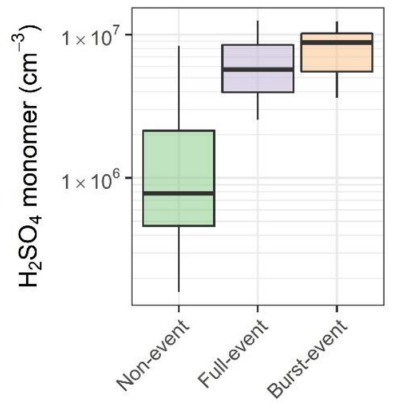

(b)

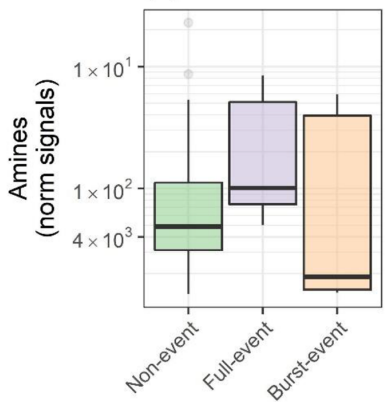

(c)

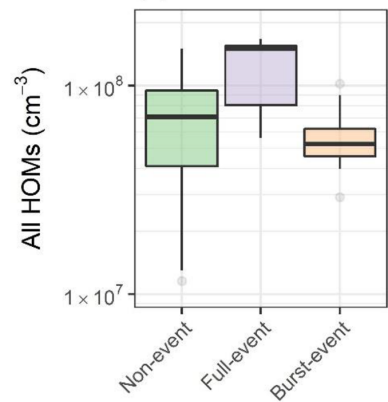

Figure 3. Box plots for days of non-event, full-event and burst-event, showing (a) sulfuric acid, (b) $\mathrm{C}_{2}$ and $\mathrm{C}_{4}$ amines, as clustered with the nitrate dimer and trimer, and (c) summed $\mathrm{HOM}$ concentration from $\mathrm{C}_{5}+$ from hourly data. Units for ammonia + amines are normalised counts, as no calibration was performed. Event days include data across the full-event day.

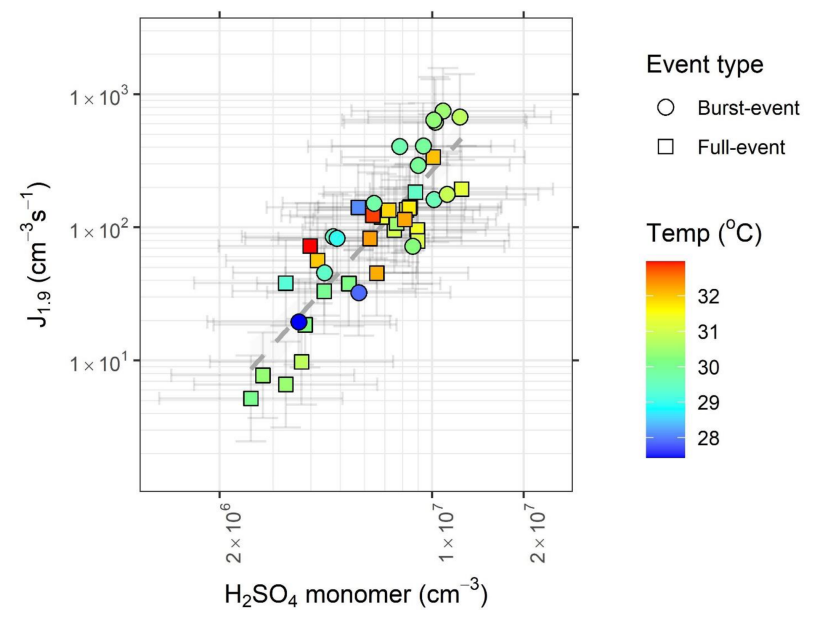

Figure 4. Formation rate $\left(J_{1.9}\right)$ plotted against sulfuric acid monomer concentration, coloured by condensation sink. Circles represent burst events and squares represent full events. Data are for hourly averages across NPF periods, typically within the hours 08:00-16:00 CEST. Slope of the line $=4.9 \times 10^{-5} \mathrm{~s}^{-1}$. Error bars represent systematic uncertainties in $\left[\mathrm{H}_{2} \mathrm{SO}_{4}\right]$ and $J_{1.9}$.

likely due to these being below the limit of detection of the instrument (Jokinen et al., 2012), so cluster identity cannot be directly identified. Sulfuric acid trimer stabilisation is dependent upon base abundance (Ortega et al., 2012), and conversely, sensitivity of Nitrate CI-APi-ToF to sulfuric acidbase clusters is reduced due to the high base content of such clusters (Jen et al., 2016).

To further explore the relationship between sulfuric acid clusters and the rate of nucleation, the sulfuric acid dimer : monomer ratio is plotted in Fig. 6. The sulfuric acid dimer: monomer ratio is elevated by the presence of gasphase bases such as DMA, and this elevation is dependent upon both the abundances and proton affinities of such bases (Olenius et al., 2017). Upon charging, evaporation of water and bases from sulfuric acid clusters occurs, and thus these

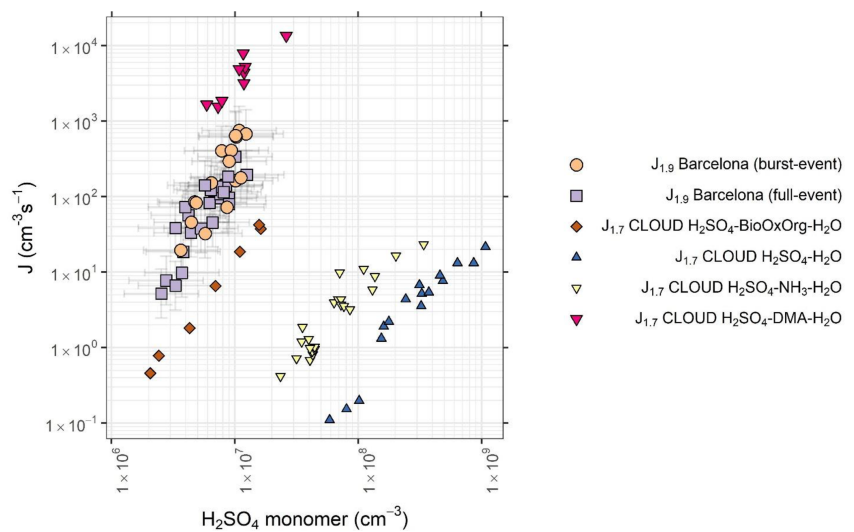

Figure 5. Formation rate plotted against sulfuric acid monomer concentration for data collected from Barcelona. Tan circles represent burst events and purple squares represent full events, as well as that for the $\mathrm{H}_{2} \mathrm{SO}_{4}-\mathrm{H}_{2} \mathrm{O}$ (blue inverted triangles), $\mathrm{H}_{2} \mathrm{SO}_{4}-\mathrm{NH}_{3}-\mathrm{H}_{2} \mathrm{O}$ (yellow inverted triangles), $\mathrm{H}_{2} \mathrm{SO}_{4}-\mathrm{DMA}-\mathrm{H}_{2} \mathrm{O}$ (pink triangles), and $\mathrm{H}_{2} \mathrm{SO}_{4}-\mathrm{BioOxOrg}-\mathrm{H}_{2} \mathrm{O}$ (brown diamonds) systems from the CLOUD chamber (Kürten et al., 2018; Kirkby et al., 2011; Riccobono et al., 2014). CLOUD chamber experiments were performed at $278 \mathrm{~K}$ and $38 \%-39 \%$ relative humidity $(\mathrm{RH})$. Data are for hourly averages across NPF periods, typically within the hours 08:0016:00. Error bars represent systematic uncertainties in $\left[\mathrm{H}_{2} \mathrm{SO}_{4}\right]$ and $J_{1.9}$.

are detected as a sulfuric acid dimer (Ortega et al., 2012, 2014). The binding energy of the bisulfate- $\mathrm{H}_{2} \mathrm{SO}_{4}$ ion is in excess of $40 \mathrm{kcal} \mathrm{mol}^{-1}$ (Curtius et al., 2001), and thus minimal declustering of the dimer is expected within the CIApi-ToF instrument - however, declustering of higher-order sulfuric acid clusters has been shown to be sensitive to voltage tune (Passananti et al., 2019), and this likely extends to the dimer also, and as such discrepancies between sets of results due to instrument setup cannot be ruled out. The ratio of sulfuric acid dimer:monomer is also highly sensitive to condensation sinks, with a difference in dimer concentration of approximately a factor of 4 expected at $10^{7} \mathrm{~cm}^{-3}$ between 
$0.001 \mathrm{~s}^{-1}$ (a clean environment) and $0.03 \mathrm{~s}^{-1}$ (condensation sinks during these NPF events measured in this dataset) (Yao et al., 2018), and thus our low dimer:monomer ratio can, in part, be explained by elevated condensation sinks. The dashed line represents the ratio that would be seen due to ion-induced clustering (IIC) in the nitrate chemical ionisation system for a $50 \mathrm{~ms}$ reaction time (Zhao et al., 2010). The sulfuric acid dimer : monomer ratio seen in the CLOUD $\mathrm{H}_{2} \mathrm{SO}_{4}-\mathrm{DMA}-\mathrm{H}_{2} \mathrm{O}$ system is plotted alongside our own data from Barcelona. The ratio from our own data is seen to be much lower than that for the system purely involving DMA as a ternary stabilising species. Similarly, this ratio is lower than for reports of $\mathrm{H}_{2} \mathrm{SO}_{4}-\mathrm{DMA}-\mathrm{H}_{2} \mathrm{O}$ nucleation in Shanghai (Yao et al., 2018) but is markedly similar to reports in central rural Germany (Kürten et al., 2016). Similarly to central Germany, this ratio increases at lower sulfuric acid concentrations to a ratio more similar to the $\mathrm{H}_{2} \mathrm{SO}_{4}-\mathrm{DMA}-\mathrm{H}_{2} \mathrm{O}$ system. A possible explanation for this is that at higher sulfuric acid concentrations, the concentrations of stronger stabilising bases are insufficient to stabilise all present sulfuric acid, with the higher end of the sulfuric acid concentrations seen in these data roughly equivalent to $1 \mathrm{pptv}$ sulfuric acid $\left(3 \times 10^{7} \mathrm{~cm}^{-3}=1.2 \mathrm{pptv}\right.$ sulfuric acid). We also cannot account for clustering due to naturally charged sulfuric acid in the atmosphere, but ion concentrations in urban environments tend to be small due to efficient sink processes (Hirsikko et al., 2011). Particle formation plausibly operates by sulfuric acid-amine nucleation involving the measured $\mathrm{C}_{2}$ and $\mathrm{C}_{4}$ amines in our data, with nucleation rates hindered relative to those measured in the CLOUD experiments by elevated temperatures, and a decline to the sulfuric acid dimer : monomer ratio indicates that base concentrations may be limited. We cannot rule out an involvement of HOMs in particle formation processes, and, as no higher-order clusters were observed, we cannot establish sulfuric acid-amine nucleation with certainty.

\subsection{HOMs and growth}

\subsubsection{HOM composition and sources}

Barcelona, as a densely populated urban agglomerate, is distinct from the remote conditions under which HOMs have primarily been studied (Bianchi et al., 2016, 2017; Schobesberger et al., 2013; Yan et al., 2016), and is characterised by elevated temperatures, insolation and $\mathrm{NO}_{x}$ mixing ratios as well as a diverse host of potential precursor VOCs. The first of these affects HOM yields significantly, as yields are highly dependent upon temperature (Quéléver et al., 2019; Stolzenburg et al., 2018). Lower temperatures result in slower $\mathrm{H}$ abstractions, which will result in the likelihood of an $\mathrm{RO}_{2}^{*}$ undergoing a different reaction pathway, such as termination with the $\mathrm{HO}_{2}^{-}$, increasing (Praske et al., 2018). This is particularly important in this study if there is a large energy barrier for the first or second $\mathrm{H}$ abstraction taking place, as

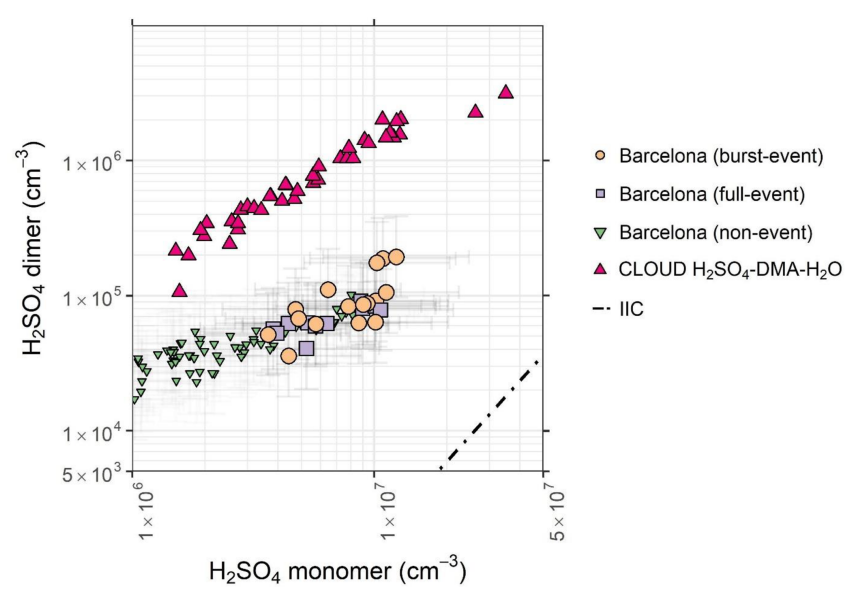

Figure 6. Sulfuric acid dimer concentration plotted against monomer concentration, showing burst-event periods (tan circles), full-event periods (purple squares), non-event periods (green inverted triangles), and the ratio of sulfuric acid dimer: monomer in the CLOUD chamber for the $\mathrm{H}_{2} \mathrm{SO}_{4}-\mathrm{H}_{2} \mathrm{O}-\mathrm{DMA}$ system (pink triangles) (Almeida et al., 2013). Dashed line represents the dimer concentration produced by ion-induced clustering in the chemical ionisation unit (Zhao et al., 2010). CLOUD chamber experiments were performed at $278 \mathrm{~K}$ and $38 \%-39 \% \mathrm{RH}$. Data are for hourly averages across NPF periods, typically within the hours 08:0016:00. Error bars represent systematic uncertainties in $\left[\mathrm{H}_{2} \mathrm{SO}_{4}\right]$ and $\left[\left(\mathrm{H}_{2} \mathrm{SO}_{4}\right)_{2}\right]$.

this will determine the number of hydrogen bond donating groups and therefore whether the $\mathrm{NO}_{3}^{-} \mathrm{CI}-\mathrm{APi}-\mathrm{ToF}$ is sensitive to a molecule or not. Elevated insolation will result in enhanced photochemistry and thus more rapid $\mathrm{RO}_{2}^{*}$ formation rates, whereas elevated $\mathrm{NO}_{x}$ will produce more $\mathrm{HOMs}$ with nitrate ester functionality (Garmash et al., 2020; Rissanen, 2018), which tend towards higher volatilities and less efficient participation in particle formation (Ehn et al., 2014; Lehtipalo et al., 2018) and growth (Yan et al., 2020).

Oxygenated volatile organic compounds (OVOCs) are defined as species visible in the Nitrate CI-APi-ToF that are not classified as HOMs. Here, the first of the three criteria provided by Bianchi et al. (2019), that HOMs must be formed by peroxy radical autoxidation, cannot be applied to define HOMs, as knowledge as to whether a molecule is a result of autoxidation requires sound knowledge of the structure of the precursors, oxidants and peroxy radical terminators present; however, the number of molecules observed with $N_{\mathrm{N}}=2$ is around an order of magnitude lower than that for $N_{\mathrm{N}}=1$, where the primary source of multiple nitrogen functionalities would be multiple peroxy radical termination reactions from $\mathrm{NO}_{x}$, and therefore while multiple generations of oxidation have been shown to occur in aromatics (Garmash et al., 2020), it is a small contributor to the concentration of what is classed as HOMs here. The second criterion to define HOMs is that they must be formed in the gas phase under atmospherically relevant conditions, which we deem appro- 
priately fulfilled as all CI-APi-ToF measurements are of gasphase compounds, and the final criterion is that HOMs must contain more than six oxygen atoms. To attempt to satisfy these criteria as well as possible, the criteria of both containing six oxygen atoms and five carbon atoms or greater and having an $\mathrm{O}: \mathrm{C}$ ratio $>0.6$ are applied.

The diversified range of HOM precursors in Barcelona will be primarily anthropogenic in origin. Averaged PTRMS mixing ratios of different VOCs are presented in Fig. S6. Figure 7a shows HOM concentration plotted against temperature, showing a dependence of HOM concentrations on temperature, with a lesser dependence on global radiation. The precursors for these HOMs are presumed to be largely isoprene, alkylbenzenes, monoterpenes, and PAHs. The mean peak intensities assigned to alkylbenzene-derived HOMs are approximately a factor of 2 higher than those assigned to isoprene and monoterpene oxidation across this entire campaign. In these data these VOC mixing ratios are, with the exception of isoprene, not largely temperature dependent, with many of these HOMs forming under negligible or zero insolation and therefore very low $\mathrm{OH}^{*}$ concentrations. These nighttime HOMs will not be derived from the oxidation of aromatics, however, as rates of oxidation of alkylbenzenes by $\mathrm{O}_{3}$ and $\mathrm{NO}_{3}^{*}$ are negligible (Molteni et al., 2018). These nighttime HOMs will therefore mostly be derived from biogenic emissions which undergo more rapid nocturnal oxidation and are likely transported from inland by the land breeze during night (Millán, 2014; Querol et al., 2017).

Operating under the assumption that $\mathrm{C}_{5}, \mathrm{C}_{6}, \mathrm{C}_{7}, \mathrm{C}_{8}$, and $\mathrm{C}_{9}$ HOMs primarily arise from isoprene, benzene toluene, and $\mathrm{C}_{2}$-alkylbenzene and $\mathrm{C}_{3}$-alkylbenzene oxidation respectively (Massoli et al., 2018; Molteni et al., 2018; Wang et al., 2017), HOM signals plotted against the parent VOC concentration indicate their dependence upon that VOC. Here, a $\mathrm{C}_{7}$ $\mathrm{HOM}$ is thought to follow the formula $\mathrm{C}_{7} \mathrm{H}_{8-12} \mathrm{O}_{5-10} \mathrm{~N}_{0-2}$. We have plotted HOM concentrations against VOC concentrations in Fig. 7b. $\mathrm{C}_{10}$ HOMs are not included in these analyses as these may primarily arise from $\mathrm{C}_{10} \mathrm{H}_{12-14}$ alkylbenzene or monoterpene oxidation. HOM concentration appears mostly independent of VOC concentration, with the exception of isoprene, for which emissions are highly temperature dependent, and thus this is likely a function of the effect of temperature on HOM formation (Fig. 7a). A lack of correlation between other VOCs and their HOMs confirms that this relationship between HOMs and temperature is not a function of enhanced VOC emission fluxes from, for example, evaporation, except in the instance of isoprene. Fragmented monoterpene oxidation products will also contribute to the total number of $\mathrm{C}_{9} \mathrm{HOMs}$, and similarly, other VOCs can fragment upon oxidation. However, these results indicate that HOM concentrations are elevated by temperature and operate quite independently of precursor VOC concentration.

DBE as calculated by Eq. (3) is equal to the number of pi bonds and rings within a molecule. Benzene, toluene, and similar aromatics have $\mathrm{DBE}=4$, naphthalene $=7$ and monoterpenes $=3$. DBE can be used as an indicator of sources when considering HOMs in bulk. Saturation mass concentration as calculated by Eq. (4) can help describe the capacity of a molecule to both condense onto newly formed particles and participate in nucleation. Figure 8 shows concentrations of HOMs and other oxygenated organic molecules binned to the nearest integer $\log _{10}\left(C^{*}\right)$ $(300 \mathrm{~K})$, coloured by DBE. Mean ion signals per carbon number are shown in Fig. S7. Most measured molecules fall into the SVOC class $\left(0.3<C^{*}(300 \mathrm{~K})<300 \mu \mathrm{g} \mathrm{m}^{-3}\right)$, which will mostly exist in equilibrium between gas and particle phase. The highest SVOC concentrations arise from fingerprint molecules for isoprene oxidation under high $\mathrm{NO}_{x}$ concentrations $\left(\mathrm{C}_{5} \mathrm{H}_{10} \mathrm{~N}_{2} \mathrm{O}_{8}\right)$ (Brean et al., 2019) and oxidation of small alkylbenzenes $\left(\mathrm{C}_{7} \mathrm{H}_{8} \mathrm{O}_{5}, \mathrm{C}_{8} \mathrm{H}_{10} \mathrm{O}_{5}\right)$. LVOCs and ELVOCs $\left(3 \times 10^{-5}<C^{*}<0.3 \mu \mathrm{g} \mathrm{m}^{-3}\right.$ and $3 \times 10^{-9}<$ $C^{*}(300 \mathrm{~K})<3 \times 10^{-5} \mu \mathrm{g} \mathrm{m}^{-3}$ respectively) have a greater contribution from molecules with higher DBE, i.e. $\mathrm{C}_{10} \mathrm{H}_{10} \mathrm{O}_{8}$ arising most likely from PAH oxidation (Molteni et al., 2018) and $\mathrm{C}_{10} \mathrm{H}_{15} \mathrm{O}_{7} \mathrm{~N}$, a common molecule arising from monoterpene oxidation in the presence of $\mathrm{NO}_{x}$. The contribution of molecules with carbon number $\leq 9$ to these LVOCs is modest, and ELVOCs are entirely comprised of molecules with carbon numbers $\geq 10$ and are dominated by DBEs of 8 and 4 , attributable to PAH and monoterpene oxidation respectively. No molecules classed as ultra-low-volatility organic compounds (ULVOCs, $C^{*}(300 \mathrm{~K})<3 \times 10^{-9} \mu \mathrm{g} \mathrm{m}^{-3}$ ) were observed in our data, and thus any pure HOM nucleation is unlikely.

\subsubsection{HOMs and NPF}

As shown in Fig. 3, an elevated HOM concentration appears to be a necessary condition for particle growth past $10 \mathrm{~nm}$ during NPF events. These days are associated with elevated temperatures, solar radiation, higher ozone, and a lower $\mathrm{NO}: \mathrm{NO}_{2}$ ratio. $\mathrm{HIO}_{3}$ is also significantly higher on burst-event days. A recent study in a remote environment reports growth rates matching condensation rates without accounting for aqueous-phase chemistry (Mohr et al., 2019). From 2D-VBS volatility calculations discussed in the previous section, it is shown that LVOCs and ELVOCs measured in Barcelona plausibly arise from the oxidation of aromatics (particularly PAHs in the case of ELVOCs) and monoterpenes. Calculated growth rates according to the method of Nieminen et al. (2010) are presented in Fig. S8 for both $\mathrm{GR}_{1.9-5}$ and $\mathrm{GR}_{5-20}$. Best agreement for $\mathrm{GR}_{5-20}$ is when condensation of SVOCs, LVOCs, ELVOCs, MSA, $\mathrm{HIO}_{3}$ and $\mathrm{H}_{2} \mathrm{SO}_{4}$ is considered, and best agreement for $\mathrm{GR}_{1.9-5}$ is seen for condensation of all these except SVOCs. The uncertainties in this method are large, and assumptions of irreversible condensation of SVOCs onto particles of $5 \mathrm{~nm}$ likely lead to overestimations; however, these results indicate an essential role of the condensation of organic compounds in producing high growth rates observed in urban environments. 

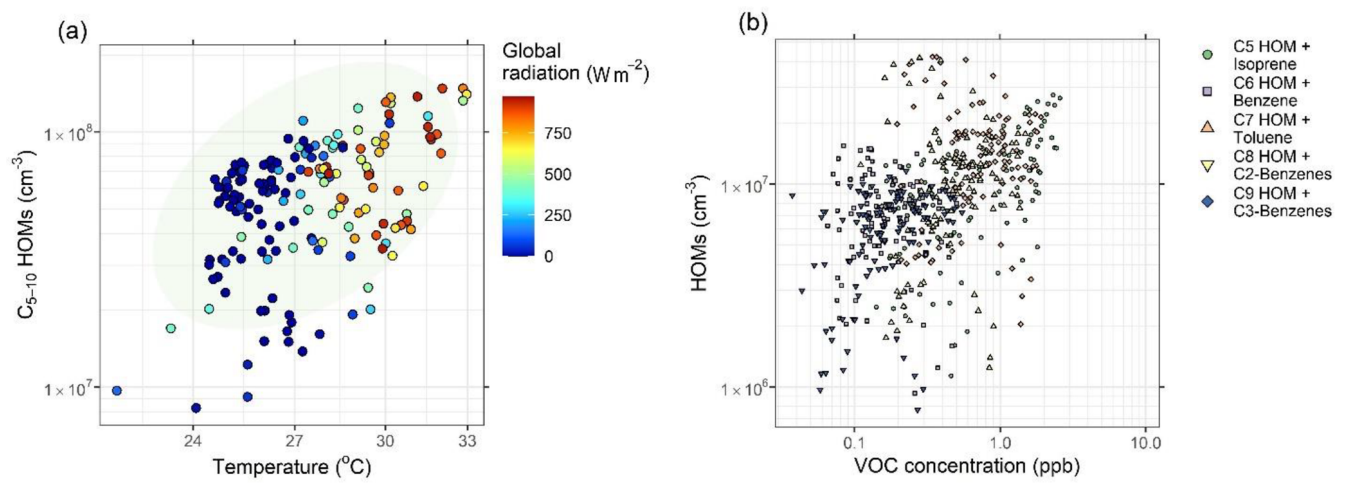

Figure 7. Influencing factors on HOM concentration, showing (a) $\mathrm{C}_{5-10} \mathrm{HOM}$ concentration plotted against temperature, coloured by global radiation. Ellipsis shows $95 \%$ confidence on a multivariate $t$ distribution. (b) HOM concentration by carbon number potted against parent VOC mixing ratio. These are segregated by carbon number / VOC, i.e. $\mathrm{C}_{7}$ HOMs plotted against toluene, under the assumption that toluene oxidation is the main producer of $\mathrm{C}_{7}$ HOMs. Time resolution for both plots is hourly.

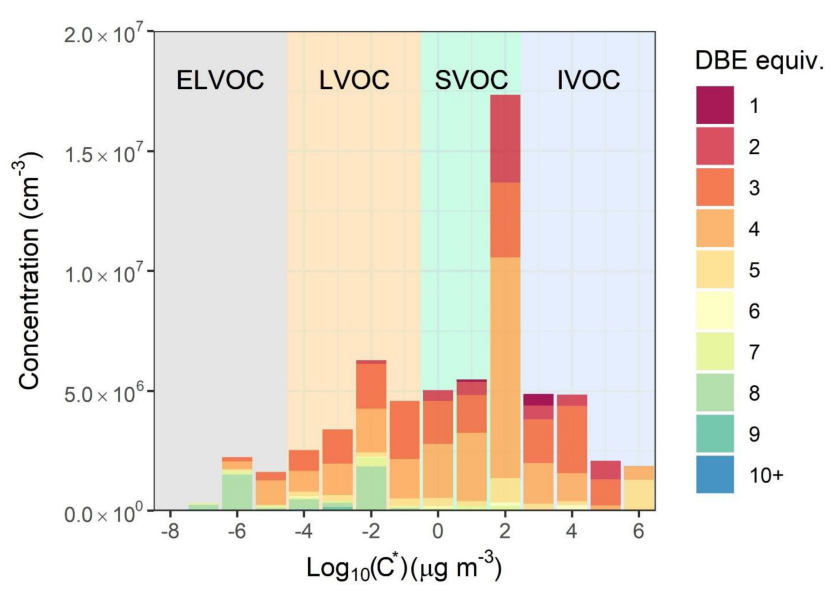

Figure 8. Concentrations of all oxygenated organic molecules and HOMs binned to integer $\log _{10}\left(C^{*}\right)$ values, coloured by DBE.

Figure 9 shows three mass-defect plots for a non-event period, full-event period, and burst-event period. The non-event day included in Fig. 8 was characterised by lower solar radiation and temperatures than average, so lower signals for oxygenated species are seen due to weaker photochemistry (i.e. $\mathrm{OH}^{*}$ concentration) and slower autoxidation due to slower H-shift reactions (Frege et al., 2018; Quéléver et al., 2019; Stolzenburg et al., 2018). The full-event day sees enhancements to smaller OVOCs and HOMs compared to the nonevent day, especially around $150-200 \mathrm{~m} \mathrm{Q}^{-1}$, which contains peaks corresponding to dicarboxylic acids and isoprene oxidation products. Some of the largest peaks in the mass spectra correspond to formulae seen arising from the enhanced $\mathrm{OH}^{*}$ oxidation of alkylbenzenes (such as $\mathrm{C}_{7} \mathrm{H}_{7} \mathrm{NO}_{6}$ ) (Molteni et al., 2018; Wang et al., 2017). Larger HOMs see a less significant enhancement to smaller alkylbenzene-derived HOMs. The presence of larger, unidentified HOMs $>400 \mathrm{~m} \mathrm{Q}^{-1}$ is enhanced during full events: these peaks will comprise the largest compounds, most likely of class ELVOC, arising from the oxidation of large VOCs, or $\mathrm{RO}_{2}^{*}-\mathrm{RO}_{2}^{*}$ accretion reactions, and thus we likely underpredict ELVOC concentrations and resultant impacts on particle growth in Fig. S8. These unidentified peaks $>400 \mathrm{~m} \mathrm{Q}^{-1}$ are both more numerous and larger during full-event periods, with a factor of 2 difference in total peak area. The burst-event day has significantly lower concentrations of OVOCs and HOMs and, to a lesser degree, their nitrogen-containing counterparts $(\mathrm{N}$ OVOCs and N-HOMs), with significantly fewer compounds $>400 \mathrm{~m} \mathrm{Q}^{-1}$. The most significant difference between fulland burst-event days is in the SVOCs, accounting for a factor of 2 difference in concentration. The sulfur-containing acids all have similar peak areas to the full-event day. These elevations to condensable OVOCs and HOMs on particle formation days with growth are consistent with particle composition data as measured by ACSM (Fig. S9). Particle composition on full-event days shows an elevation to organic mass concentration in the late evening and night around when new particles from NPF will reach sizes detectable by the ACSM ( $\sim 75 \mathrm{~nm}, \mathrm{Ng}$ et al., 2011). Organic mass between 16:00 and 23:00 CEST is $3.5 \mu \mathrm{g} \mathrm{m}^{-3}$ on burst-event days versus $7.8 \mu \mathrm{g} \mathrm{m}^{-3}$ on full-event days.

\section{Conclusions}

We show new particle formation rates in Barcelona are linearly dependent upon the sulfuric acid concentrations, and while formation rates far exceed that of $\mathrm{H}_{2} \mathrm{SO}_{4-}$ BioOxOrg- $\mathrm{H}_{2} \mathrm{O}$ nucleation, they fall short of those of $\mathrm{H}_{2} \mathrm{SO}_{4}-\mathrm{DMA}-\mathrm{H}_{2} \mathrm{O}$ nucleation at $278 \mathrm{~K}$, as does the sulfuric acid dimer: monomer ratio, possibly explained by cluster evaporation due to high temperatures in summertime Barcelona (303 K during events), and limited pools of gasphase amines. These results are similar to reports of nucleation rates in rural Germany (Kürten et al., 2016). As no 

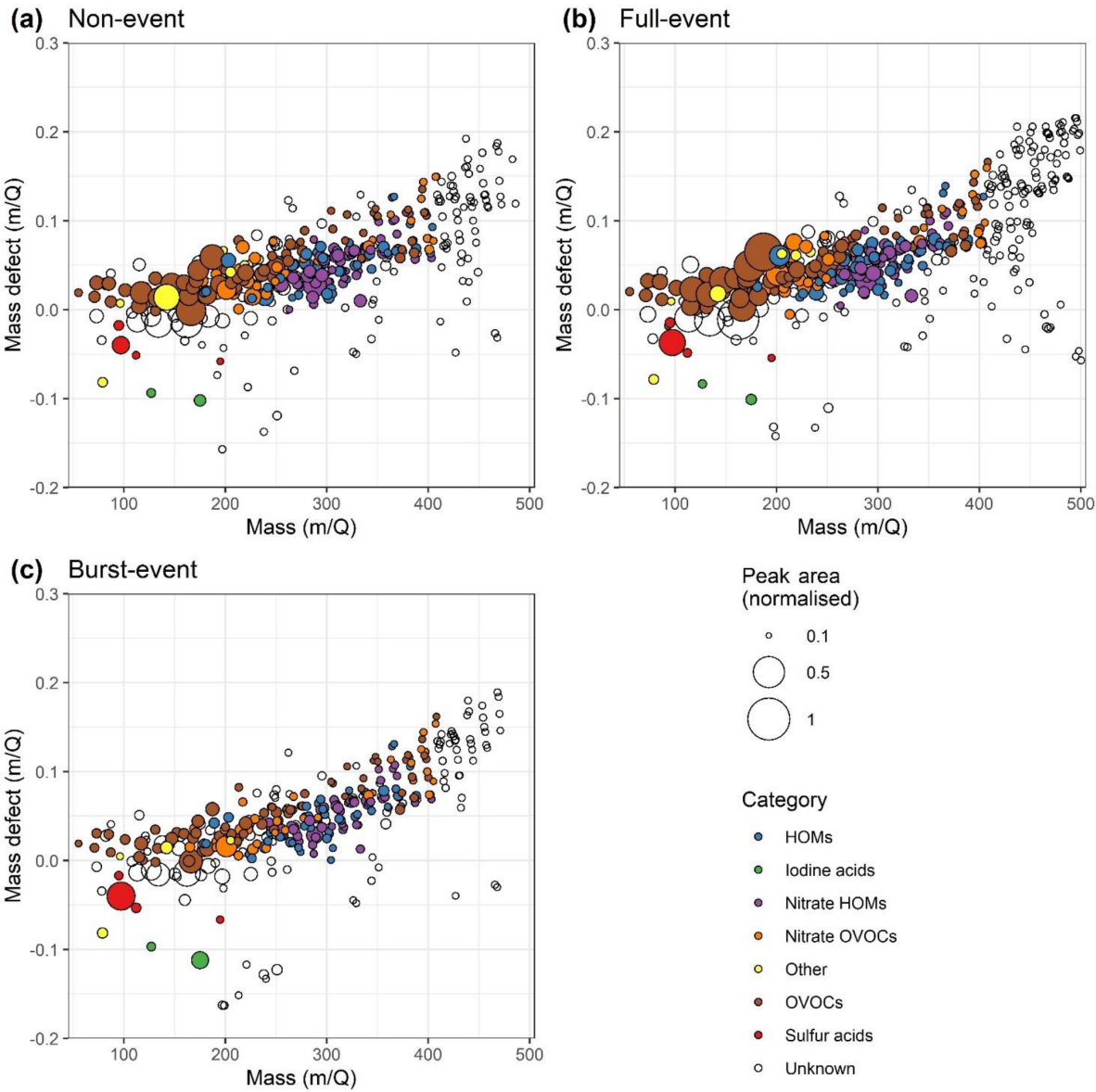

Figure 9. Mass-defect plots for (a) non-event, (b) full-event, and (c) burst-event periods; data taken from 10:00 to 15:00 on the days 11, 16 and 15 July 2018 respectively. Size corresponds to mass spectral peak area. Ions are coloured according to identified chemical composition. Blue points correspond to HOMs containing all organic species with $\geq 5$ carbon atoms and $\geq 6$ oxygen atoms and an $\mathrm{O}: \mathrm{C}$ ratio of $>0.6$. Purple points correspond to the same but for species containing one to two nitrogen atoms. Species not meeting this HOM criterion were classed generally as OVOCs which are coloured brown, with the nitrogen-containing OVOCs coloured orange. Sulfur acids (red) include ions $\mathrm{HSO}_{4}^{-}, \mathrm{CH}_{3} \mathrm{SO}_{3}^{-}$and $\mathrm{SO}_{5}^{-}$as well as the sulfuric acid dimer. Iodine acids (green) contain both $\mathrm{IO}_{3}^{-}$and $\mathrm{I}^{-}$(the latter presumably deprotonated hydrogen iodide). Unidentified points are left uncoloured.

higher-order clusters were directly measured, we cannot determine nucleation mechanisms with certainty, and an involvement of HOMs in nucleation is plausible.

High concentrations of OVOCs and HOMs were measured by CI-APi-ToF. Of these, the SVOCs arose from mostly isoprene and alkylbenzene oxidation, whereas LVOCs and ELVOCs arose from alkylbenzene, monoterpene and PAH oxidation together, with a dependence of their concentration on temperature. Concentrations of species associated with coastal and oceanic sources such as MSA and $\mathrm{HIO}_{3}$ were low. High HOM concentrations are seen to be a necessary condition for new particle growth past $10 \mathrm{~nm}$, with the most significant difference between days with and without particle growth being SVOC concentrations (factor of 2 difference), while modelled growth rates from condensation of these organic compounds, alongside $\mathrm{H}_{2} \mathrm{SO}_{4}$, MSA and $\mathrm{HIO}_{3}$, were shown to match growth rates within measure- ment error. Thus, oxidation of traffic-derived alkylbenzenes and PAHs, and, to a lesser degree, isoprene and monoterpene emissions, is a significant determinant of new particle growth in this environment.

These results are consistent with extensive chamber and flow tube studies on particle formation from sulfuric acid, amines and HOMs, and further, nucleation rates relative to sulfuric acid are similar to many tropospheric observations. Barcelona is representative of many Mediterranean urban environments, with moderate pollution, influence of shipping emissions, and high insolation, and the present study reveals the complexity of NPF mechanisms in these environments. 
Data availability. Data supporting this publication are openly available from the UBIRA eData repository at https://doi.org/10. 25500/edata.bham.00000434 (Harrison and Brean, 2020).

Supplement. The supplement related to this article is available online at: https://doi.org/10.5194/acp-20-10029-2020-supplement.

Author contributions. RMH and XQ conceived the study and JB and DCSB carried out the CI-APi-TOF and related measurements with assistance from AA and MCM. The VOC measurements were proposed by NM and collected by BTR. JB wrote the first draft of the manuscript which was enhanced by contributions from the coauthors.

Competing interests. The authors declare that they have no conflict of interest.

Acknowledgements. María Cruz Minguillón acknowledges the Ramón y Cajal Fellowship awarded by the Spanish Ministry of Science, Innovation and Universities.

Financial support. This research has been supported by the Spanish Ministry of Science, Innovation and Universities and Competitiveness and FEDER funds (project HOUSE (grant no. CGL201678594-R)), the Generalitat de Catalunya (grant no. AGAUR 2017 SGR41), and the Natural Environment Research Council (grant no. $\mathrm{R} 8 / \mathrm{H} 12 / 83 / 011)$.

Review statement. This paper was edited by Veli-Matti Kerminen and reviewed by two anonymous referees.

\section{References}

Ábalos, M., Bayona, J. M., and Ventura, F.: Development of a solid-phase microextraction GC-NPD procedure for the determination of free volatile amines in wastewater and sewage-polluted waters, Anal. Chem., 71, 3531-3537, https://doi.org/10.1021/ac990197h, 1999.

Almeida, J., Schobesberger, S., Kürten, A., Ortega, I. K., Kupiainen-Määttä, O., Praplan, A. P., Adamov, A., Amorim, A., Bianchi, F., Breitenlechner, M., David, A., Dommen, J., Donahue, N. M., Downard, A., Dunne, E., Duplissy, J., Ehrhart, S., Flagan, R. C., Franchin, A., Guida, R., Hakala, J., Hansel, A., Heinritzi, M., Henschel, H., Jokinen, T., Junninen, H., Kajos, M., Kangasluoma, J., Keskinen, H., Kupc, A., Kurtén, T., Kvashin, A. N., Laaksonen, A., Lehtipalo, K., Leiminger, M., Leppä, J., Loukonen, V., Makhmutov, V., Mathot, S., McGrath, M. J., Nieminen, T., Olenius, T., Onnela, A., Petäjä, T., Riccobono, F., Riipinen, I., Rissanen, M., Rondo, L., Ruuskanen, T., Santos, F. D., Sarnela, N., Schallhart, S., Schnitzhofer, R., Seinfeld, J. H., Simon, M., Sipilä, M., Stozhkov, Y., Stratmann, F., Tomé, A.,
Tröstl, J., Tsagkogeorgas, G., Vaattovaara, P., Viisanen, Y., Virtanen, A., Vrtala, A., Wagner, P. E., Weingartner, E., Wex, H., Williamson, C., Wimmer, D., Ye, P., Yli-Juuti, T., Carslaw, K. S., Kulmala, M., Curtius, J., Baltensperger, U., Worsnop, D. R., Vehkamäki, H., and Kirkby, J.: Molecular understanding of sulphuric acid-amine particle nucleation in the atmosphere, Nature, 502, 359-363, https://doi.org/10.1038/nature12663, 2013.

Bianchi, F., Tröstl, J., Junninen, H., Frege, C., Henne, S., Hoyle, C. R., Molteni, U., Herrmann, E., Bukowiecki, N., Chen, X., Duplissy, J., Gysel, M., Hutterli, M., Kangasluoma, J., Kontkanen, J., Manninen, H. E., Münch, S., Peräkylä, O., Petäjä, T., Rondo, L., Williamson, C., Weingartner, E., Worsnop, D. R., Kulmala, M., Dommen, J., and Baltensperger, U.: New particle formation in the free troposphere?: A question of chemistry and timing, Science, 5456, 1-11, 2016.

Bianchi, F., Garmash, O., He, X., Yan, C., Iyer, S., Rosendahl, I., Xu, Z., Rissanen, M. P., Riva, M., Taipale, R., Sarnela, N., Petäjä, T., Worsnop, D. R., Kulmala, M., Ehn, M., and Junninen, H.: The role of highly oxygenated molecules (HOMs) in determining the composition of ambient ions in the boreal forest, Atmos. Chem. Phys., 17, 13819-13831, https://doi.org/10.5194/acp-17-138192017, 2017.

Bianchi, F., Kurtén, T., Riva, M., Mohr, C., Rissanen, M. P., Roldin, P., Berndt, T., Crounse, J. D., Wennberg, P. O., Mentel, T. F., Wildt, J., Junninen, H., Jokinen, T., Kulmala, M., Worsnop, D. R., Thornton, J. A., Donahue, N., Kjaergaard, H. G., and Ehn, M.: Highly Oxygenated Organic Molecules (HOM) from GasPhase Autoxidation Involving Peroxy Radicals: A Key Contributor to Atmospheric Aerosol, Chem. Rev., 119, 3472-3509, https://doi.org/10.1021/acs.chemrev.8b00395, 2019.

Bousiotis, D., Dall'Osto, M., Beddows, D. C. S., Pope, F. D., and Harrison, R. M.: Analysis of new particle formation (NPF) events at nearby rural, urban background and urban roadside sites, Atmos. Chem. Phys., 19, 5679-5694, https://doi.org/10.5194/acp19-5679-2019, 2019.

Brean, J., Harrison, R. M., Shi, Z., Beddows, D. C. S., Acton, W. J. F., Hewitt, C. N., Squires, F. A., and Lee, J.: Observations of highly oxidized molecules and particle nucleation in the atmosphere of Beijing, Atmos. Chem. Phys., 19, 14933-14947, https://doi.org/10.5194/acp-19-14933-2019, 2019.

Brines, M., Dall'Osto, M., Beddows, D. C. S., Harrison, R. M., and Querol, X.: Simplifying aerosol size distributions modes simultaneously detected at four monitoring sites during SAPUSS, Atmos. Chem. Phys., 14, 2973-2986, https://doi.org/10.5194/acp14-2973-2014, 2014.

Brines, M., Dall'Osto, M., Beddows, D. C. S., Harrison, R. M., Gómez-Moreno, F., Núñez, L., Artíñano, B., Costabile, F., Gobbi, G. P., Salimi, F., Morawska, L., Sioutas, C., and Querol, X.: Traffic and nucleation events as main sources of ultrafine particles in high-insolation developed world cities, Atmos. Chem. Phys., 15, 5929-5945, https://doi.org/10.5194/acp15-5929-2015, 2015.

Cadle, S. H. and Mulawa, P. A.: Low-molecular-weight aliphatic amines in exhaust from catalyst-equipped cars, Environ. Sci Technol., 14, 718-723, https://doi.org/10.1021/es60166a011, 1980.

Carnerero, C., Pérez, N., Petäjä, T., Laurila, T. M., Ahonen, L. R., Kontkanen, J., Ahn, K. H., Alastuey, A., and Querol, X.: Relating high ozone, ultrafine particles, and new particle forma- 
tion episodes using cluster analysis, Atmos. Environ. X, 4, 1-20, https://doi.org/10.1016/j.aeaoa.2019.100051, 2019.

Cohen, A. J., Brauer, M., Burnett, R., Anderson, H. R., Frostad, J., Estep, K., Balakrishnan, K., Brunekreef, B., Dandona, L., Dandona, R., Feigin, V., Freedman, G., Hubbell, B., Jobling, A., Kan, H., Knibbs, L., Liu, Y., Martin, R., Morawska, L., Pope, C. A., Shin, H., Straif, K., Shaddick, G., Thomas, M., van Dingenen, R., van Donkelaar, A., Vos, T., Murray, C. J. L., and Forouzanfar, M. H.: Estimates and 25-year trends of the global burden of disease attributable to ambient air pollution: an analysis of data from the Global Burden of Diseases Study 2015, Lancet, 389, 1907-1918, https://doi.org/10.1016/S0140-6736(17)30505-6, 2017.

Cubison, M. J. and Jimenez, J. L.: Statistical precision of the intensities retrieved from constrained fitting of overlapping peaks in high-resolution mass spectra, Atmos. Meas. Tech., 8, 23332345, https://doi.org/10.5194/amt-8-2333-2015, 2015.

Curtius, J., Froyd, K. D., and Lovejoy, E. R.: Cluster ion thermal decomposition (I): Experimental kinetics study and ab initio calculations for $\mathrm{HSO}_{4}^{-}\left(\mathrm{H}_{2} \mathrm{~S}_{4}\right)_{x}\left(\mathrm{HNO}_{3}\right)_{y}$, J. Phys. Chem. A, 105, 10867-10873, https://doi.org/10.1021/jp0124950, 2001.

Dal Maso, M., Kulmala, M., Riipinen, I., Wagner, R., Hussein, T., Aalto, P. P., and Lehtinen, K. E. J.: Formation and growth of fresh atmospheric aerosols: Eight years of aerosol size distribution data from SMEAR II, Hyytiälä, Finland, Boreal Environ. Res., 10, 323-336, 2005.

Dall'Osto, M., Querol, X., Alastuey, A., O’Dowd, C., Harrison, R. M., Wenger, J., and Gómez-Moreno, F. J.: On the spatial distribution and evolution of ultrafine particles in Barcelona, Atmos. Chem. Phys., 13, 741-759, https://doi.org/10.5194/acp-13-7412013, 2013.

Donahue, N. M., Epstein, S. A., Pandis, S. N., and Robinson, A. L.: A two-dimensional volatility basis set: 1. organic-aerosol mixing thermodynamics, Atmos. Chem. Phys., 11, 3303-3318, https://doi.org/10.5194/acp-11-3303-2011, 2011.

Ehn, M., Thornton, J. A., Kleist, E., Sipilä, M., Junninen, H., Pullinen, I., Springer, M., Rubach, F., Tillmann, R., Lee, B., Lopez-Hilfiker, F., Andres, S., Acir, I.-H., Rissanen, M., Jokinen, T., Schobesberger, S., Kangasluoma, J., Kontkanen, J., Nieminen, T., Kurtén, T., Nielsen, L. B., Jørgensen, S., Kjaergaard, H. G., Canagaratna, M., Maso, M. D., Berndt, T., Petäjä, T., Wahner, A., Kerminen, V.-M., Kulmala, M., Worsnop, D. R., Wildt, J., and Mentel, T. F.: A large source of lowvolatility secondary organic aerosol, Nature, 506, 476-479, https://doi.org/10.1038/nature13032, 2014.

Frege, C., Ortega, I. K., Rissanen, M. P., Praplan, A. P., Steiner, G., Heinritzi, M., Ahonen, L., Amorim, A., Bernhammer, A.-K., Bianchi, F., Brilke, S., Breitenlechner, M., Dada, L., Dias, A., Duplissy, J., Ehrhart, S., El-Haddad, I., Fischer, L., Fuchs, C., Garmash, O., Gonin, M., Hansel, A., Hoyle, C. R., Jokinen, T., Junninen, H., Kirkby, J., Kürten, A., Lehtipalo, K., Leiminger, M., Mauldin, R. L., Molteni, U., Nichman, L., Petäjä, T., Sarnela, N., Schobesberger, S., Simon, M., Sipilä, M., Stolzenburg, D., Tomé, A., Vogel, A. L., Wagner, A. C., Wagner, R., Xiao, M., Yan, C., Ye, P., Curtius, J., Donahue, N. M., Flagan, R. C., Kulmala, M., Worsnop, D. R., Winkler, P. M., Dommen, J., and Baltensperger, U.: Influence of temperature on the molecular composition of ions and charged clusters during pure biogenic nucleation, Atmos. Chem. Phys., 18, 65-79, https://doi.org/10.5194/acp-18-65-2018, 2018.
Garmash, O., Rissanen, M. P., Pullinen, I., Schmitt, S., Kausiala, O., Tillmann, R., Zhao, D., Percival, C., Bannan, T. J., Priestley, M., Hallquist, Å. M., Kleist, E., Kiendler-Scharr, A., Hallquist, M., Berndt, T., McFiggans, G., Wildt, J., Mentel, T. F., and Ehn, M.: Multi-generation $\mathrm{OH}$ oxidation as a source for highly oxygenated organic molecules from aromatics, Atmos. Chem. Phys. 20, 515-537, https://doi.org/10.5194/acp-20-515-2020, 2020.

Ge, X., Wexler, A. S., and Clegg, S. L.: Atmospheric amines - Part I. A review, Atmos. Environ., 45, 524-546, https://doi.org/10.1016/j.atmosenv.2010.10.012, 2011 a.

Ge, X., Wexler, A. S., and Clegg, S. L.: Atmospheric amines - Part II. Thermodynamic properties and gas/particle partitioning, Atmos. Environ., 45, 561-577, https://doi.org/10.1016/j.atmosenv.2010.10.013, 2011 b.

Graus, M., Müller, M., and Hansel, A.: High resolution PTRTOF: Quantification and Formula Confirmation of VOC in Real Time, J. Am. Soc. Mass Spectrom., 21, 1037-1044, https://doi.org/10.1016/j.jasms.2010.02.006, 2010.

Guo, S., Hu, M., Zamora, M. L., Peng, J., Shang, D., Zheng, J., Du, Z., Wu, Z., Shao, M., Zeng, L., Molina, M. J., and Zhang, R.: Elucidating severe urban haze formation in China, P. Natl. Acad. Sci. USA, 111, 17373-17378, https://doi.org/10.1073/pnas.1419604111, 2014.

Harrison, R. and Brean, J.: Particle nucleation study in Barcelona, University of Birmingham, https://doi.org/10.25500/edata.bham.00000434, 2020.

Harrison, R. M., Rob Mackenzie, A., Xu, H., Alam, M. S., Nikolova, I., Zhong, J., Singh, A., Zeraati-Rezaei, S., Stark, C., Beddows, D. C. S., Liang, Z., Xu, R., and Cai, X.: Diesel exhaust nanoparticles and their behaviour in the atmosphere, P. R. Soc. A, 474, 20180492, https://doi.org/10.1098/rspa.2018.0492, 2018.

Henschel, S., Querol, X., Atkinson, R., Pandolfi, M., Zeka, A., Tertre, A. L., Analistis, A., Katsouyanni, K., Chanel, O., Pascal, M., Bouland, C., Haluza, D., Medina, S., and Goodman, P. G.: Ambient air $\mathrm{SO}_{2}$ patterns in 6 European cities, Atmos. Environ., 79, 236-247, https://doi.org/10.1016/j.atmosenv.2013.06.008, 2013.

Hirsikko, A., Nieminen, T., Gagné, S., Lehtipalo, K., Manninen, H. E., Ehn, M., Hõrrak, U., Kerminen, V.-M., Laakso, L., McMurry, P. H., Mirme, A., Mirme, S., Petäjä, T., Tammet, H., Vakkari, V., Vana, M., and Kulmala, M.: Atmospheric ions and nucleation: a review of observations, Atmos. Chem. Phys., 11, 767798, https://doi.org/10.5194/acp-11-767-2011, 2011.

Hutchinson, G. L., Mosier, A. R., and Andre, C. E.: Ammonia and Amine Emissions from a Large Cattle Feedlot, J. Environ. Qual., 11, 288-293, 1982.

Hyttinen, N., Kupiainen-Määtta, O., Rissanen, M. P., Muuronen, M., Ehn, M., and Kurtén, T.: Modeling the Charging of Highly Oxidized Cyclohexene Ozonolysis Products Using Nitrate-Based Chemical Ionization, J. Phys. Chem. A, 119, 6339-6345, https://doi.org/10.1021/acs.jpca.5b01818, 2015.

IPCC: Climate Change 2013: The Physical Science Basis. Contribution of Working Group I to the Fifth Assessment Report of the Intergovernmental Panel on Climate Change, edited by: Stocker, T. F., Qin, D., Plattner, G.-K., Tignor, M., Allen. S. K., Boschung, J., Nauels, A., Xia, Y., Bex, V., and Midgley, P. M., Cambridge University Press, Cambridge, 2013. 
Jen, C. N., Zhao, J., McMurry, P. H., and Hanson, D. R.: Chemical ionization of clusters formed from sulfuric acid and dimethylamine or diamines, Atmos. Chem. Phys., 16, 12513-12529, https://doi.org/10.5194/acp-16-12513-2016, 2016.

Jokinen, T., Sipilä, M., Junninen, H., Ehn, M., Lönn, G., Hakala, J., Petäjä, T., Mauldin III, R. L., Kulmala, M., and Worsnop, D. R.: Atmospheric sulphuric acid and neutral cluster measurements using CI-APi-TOF, Atmos. Chem. Phys., 12, 4117-4125, https://doi.org/10.5194/acp-12-4117-2012, 2012.

Jokinen, T., Sipilä, M., Kontkanen, J., Vakkari, V., Tisler, P., Duplissy, E.-M., Junninen, H., Kangasluoma, J., Manninen, H. E., Petäjä, T., Kulmala, M., Worsnop, D. R., Kirkby, J., Virkkula, A., and Kerminen, V.-M.: Ion-induced sulphuric acid-ammonia nucleation drives particle formation in coastal Antarctica, Sci. Adv., 4, eaat9744, https://doi.org/10.1126/sciadv.aat9744, 2018.

Junninen, H., Ehn, M., Petäjä, T., Luosujärvi, L., Kotiaho, T., Kostiainen, R., Rohner, U., Gonin, M., Fuhrer, K., Kulmala, M., and Worsnop, D. R.: A high-resolution mass spectrometer to measure atmospheric ion composition, Atmos. Meas. Tech., 3, 10391053, https://doi.org/10.5194/amt-3-1039-2010, 2010.

Kerminen, V. M., Chen, X., Vakkari, V., Petäjä, T., Kulmala, M., and Bianchi, F.: Atmospheric new particle formation and growth: Review of field observations, Environ. Res. Lett., 13, 10, https://doi.org/10.1088/1748-9326/aadf3c, 2018.

Kirkby, J., Curtius, J., Almeida, J., Dunne, E., Duplissy, J., Ehrhart, S., Franchin, A., Gagné, S., Ickes, L., Kürten, A., Kupc, A., Metzger, A., Riccobono, F., Rondo, L., Schobesberger, S., Tsagkogeorgas, G., Wimmer, D., Amorim, A., Bianchi, F., Breitenlechner, M., David, A., Dommen, J., Downard, A., Ehn, M., Flagan, R. C., Haider, S., Hansel, A., Hauser, D., Jud, W., Junninen, H., Kreissl, F., Kvashin, A., Laaksonen, A., Lehtipalo, K., Lima, J., Lovejoy, E. R., Makhmutov, V., Mathot, S., Mikkilä, J., Minginette, P., Mogo, S., Nieminen, T., Onnela, A., Pereira, P., Petäjä, T., Schnitzhofer, R., Seinfeld, J. H., Sipilä, M., Stozhkov, Y., Stratmann, F., Tomé, A., Vanhanen, J., Viisanen, Y., Vrtala, A., Wagner, P. E., Walther, H., Weingartner, E., Wex, H., Winkler, P. M., Carslaw, K. S., Worsnop, D. R., Baltensperger, U., and Kulmala, M.: Role of sulphuric acid, ammonia and galactic cosmic rays in atmospheric aerosol nucleation, Nature, 476, 429-435, https://doi.org/10.1038/nature10343, 2011.

Kuang, C., McMurry, P. H., McCormick, A. V., and Eisele, F. L.: Dependence of nucleation rates on sulfuric acid vapor concentration in diverse atmospheric locations, J. Geophys. Res.-Atmos., 113, 1-9, https://doi.org/10.1029/2007JD009253, 2008.

Kulmala, M., Dal Maso, M., Mäkelä, J. M., Pirjola, L., Väkevä, M., Aalto, P., Miikkulainen, P., Hämeri, K., and O’Dowd, C. D.: On the formation, growth and composition of nucleation mode particles, Tellus B, 53, 479-490, https://doi.org/10.1034/j.16000889.2001.d01-33.x, 2001.

Kulmala, M., Petäjä, T., Nieminen, T., Sipilä, M., Manninen, H. E., Lehtipalo, K., Dal Maso, M., Aalto, P. P., Junninen, H., Paasonen, P., Riipinen, I., Lehtinen, K. E. J., Laaksonen, A., and Kerminen, V.-M.: Measurement of the nucleation of atmospheric aerosol particles, Nat. Protoc., 7, 1651-1667, https://doi.org/10.1038/nprot.2012.091, 2012.

Kulmala, M., Kerminen, V. M., Petäjä, T., Ding, A. J., and Wang, L.: Atmospheric gas-to-particle conversion: Why NPF events are observed in megacities?, Faraday Discuss., 200, 271-288, https://doi.org/10.1039/c6fd00257a, 2017.
Kürten, A., Jokinen, T., Simon, M., Sipilä, M., Sarnela, N., Junninen, H., Adamov, A., Almeida, J., Amorim, A., Bianchi, F., Breitenlechner, M., Dommen, J., Donahue, N. M., Duplissy, J., Ehrhart, S., Flagan, R. C., Franchin, A., Hakala, J., Hansel, A., Heinritzi, M., Hutterli, M., Kangasluoma, J., Kirkby, J., Laaksonen, A., Lehtipalo, K., Leiminger, M., Makhmutov, V., Mathot, S., Onnela, A., Petäjä, T., Praplan, A. P., Riccobono, F., Rissanen, M. P., Rondo, L., Schobesberger, S., Seinfeld, J. H., Steiner, G., Tomé, A., Tröstl, J., Winkler, P. M., Williamson, C., Wimmer, D., Ye, P., Baltensperger, U., Carslaw, K. S., Kulmala, M., Worsnop, D. R., and Curtius, J.: Neutral molecular cluster formation of sulfuric acid-dimethylamine observed in real time under atmospheric conditions, P. Natl. Acad. Sci. USA, 111, 1501915024, https://doi.org/10.1073/pnas.1404853111, 2014.

Kürten, A., Bergen, A., Heinritzi, M., Leiminger, M., Lorenz, V., Piel, F., Simon, M., Sitals, R., Wagner, A. C., and Curtius, J.: Observation of new particle formation and measurement of sulfuric acid, ammonia, amines and highly oxidized organic molecules at a rural site in central Germany, Atmos. Chem. Phys., 16, 1279312813, https://doi.org/10.5194/acp-16-12793-2016, 2016.

Kürten, A., Li, C., Bianchi, F., Curtius, J., Dias, A., Donahue, N. M., Duplissy, J., Flagan, R. C., Hakala, J., Jokinen, T., Kirkby, J., Kulmala, M., Laaksonen, A., Lehtipalo, K., Makhmutov, V., Onnela, A., Rissanen, M. P., Simon, M., Sipilä, M., Stozhkov, Y., Tröstl, J., Ye, P., and McMurry, P. H.: New particle formation in the sulfuric acid-dimethylamine-water system: reevaluation of CLOUD chamber measurements and comparison to an aerosol nucleation and growth model, Atmos. Chem. Phys., 18, 845-863, https://doi.org/10.5194/acp-18-845-2018, 2018.

Kurtén, T., Noppel, M., Vehkamäki, H., Salonen, M., and Kulmala, M.: Quantum chemical studies of hydrate formation of $\mathrm{H}_{2} \mathrm{SO}_{4}$ and $\mathrm{HSO}_{4}^{-}$, Boreal Environ. Res., 12, 431-453, 2007.

Lee, S. H., Gordon, H., Yu, H., Lehtipalo, K., Haley, R., Li, Y., and Zhang, R.: New Particle Formation in the Atmosphere: From Molecular Clusters to Global Climate, J. Geophys. Res.-Atmos., 124, 7098-7146, https://doi.org/10.1029/2018JD029356, 2019.

Lehtinen, K. E. J., Dal Maso, M., Kulmala, M., and Kerminen, V. M.: Estimating nucleation rates from apparent particle formation rates and vice versa: Revised formulation of the Kerminen-Kulmala equation, J. Aerosol Sci., 38, 988-994, https://doi.org/10.1016/j.jaerosci.2007.06.009, 2007.

Lehtipalo, K., Yan, C., Dada, L., Bianchi, F., Xiao, M., Wagner, R., Stolzenburg, D., Ahonen, L. R., Amorim, A., Baccarini, A., Bauer, P. S., Baumgartner, B., Bergen, A., Bernhammer, A.-K., Breitenlechner, M., Brilke, S., Buchholz, A., Mazon, S. B., Chen, D., Chen, X., Dias, A., Dommen, J., Draper, D. C., Duplissy, J., Ehn, M., Finkenzeller, H., Fischer, L., Frege, C., Fuchs, C., Garmash, O., Gordon, H., Hakala, J., He, X., Heikkinen, L., Heinritzi, M., Helm, J. C., Hofbauer, V., Hoyle, C. R., Jokinen, T., Kangasluoma, J., Kerminen, V.-M., Kim, C., Kirkby, J., Kontkanen, J., Kürten, A., Lawler, M. J., Mai, H., Mathot, S., Mauldin, R. L., Molteni, U., Nichman, L., Nie, W., Nieminen, T., Ojdanic, A., Onnela, A., Passananti, M., Petäjä, T., Piel, F., Pospisilova, V., Quéléver, L. L. J., Rissanen, M. P., Rose, C., Sarnela, N., Schallhart, S., Schuchmann, S., Sengupta, K., Simon, M., Sipilä, M., Tauber, C., Tomé, A., Tröstl, J., Väisänen, O., Vogel, A. L., Volkamer, R., Wagner, A. C., Wang, M., Weitz, L., Wimmer, D., Ye, P., Ylisirniö, A., Zha, Q., Carslaw, K. S., Curtius, J., Donahue, N. M., Flagan, R. C., Hansel, A., Riipinen, I., Virtanen, A., 
Winkler, P. M., Baltensperger, U., Kulmala, M., and Worsnop, D. R.: Multicomponent new particle formation from sulphuric acid, ammonia, and biogenic vapors, Sci. Adv., 4, eaau5363, https://doi.org/10.1126/sciadv.aau5363, 2018.

Massoli, P., Stark, H., Canagaratna, M. R., Krechmer, J. E., Xu, L., Ng, N. L., Mauldin, R. L., Yan, C., Kimmel, J., Misztal, P. K., Jimenez, J. L., Jayne, J. T., and Worsnop, D. R.: Ambient Measurements of Highly Oxidized GasPhase Molecules during the Southern Oxidant and Aerosol Study (SOAS) 2013, ACS Earth Space Chem., 2, 653-672, https://doi.org/10.1021/acsearthspacechem.8b00028, 2018.

Mikkonen, S., Romakkaniemi, S., Smith, J. N., Korhonen, H., Petäjä, T., Plass-Duelmer, C., Boy, M., McMurry, P. H., Lehtinen, K. E. J., Joutsensaari, J., Hamed, A., Mauldin III, R. L., Birmili, W., Spindler, G., Arnold, F., Kulmala, M., and Laaksonen, A.: A statistical proxy for sulphuric acid concentration, Atmos. Chem. Phys., 11, 11319-11334, https://doi.org/10.5194/acp-1111319-2011, 2011

Millán, M.: Extreme hydrometeorological events and climate change predictions in Europe, J. Hydrol., 518, 206-224, https://doi.org/10.1016/j.jhydrol.2013.12.041, 2014.

Miller, M. R., Raftis, J. B., Langrish, J. P., McLean, S. G., Samutrtai, P., Connell, S. P., Wilson, S., Vesey, A. T., Fokkens, P. H. B., Boere, A. J. F., Krystek, P., Campbell, C. J., Hadoke, P. W. F., Donaldson, K., Cassee, F. R., Newby, D. E., Duffin, R., and Mills, N. L.: Inhaled Nanoparticles Accumulate at Sites of Vascular Disease, ACS Nano, 11, 4542-4552, https://doi.org/10.1021/acsnano.6b08551, 2017.

Minguillón, M. C., Brines, M., Pérez, N., Reche, C., Pandol, M., Fonseca, A. S., Amato, F., Alastuey, A., Lyasota, A., Codina, B., Lee, H., Eun, H., Ahn, K., and Querol, X.: New particle formation at ground level and in the vertical column over the Barcelona area, Atmos. Res., 165, 118-130, https://doi.org/10.1016/j.atmosres.2015.05.003, 2015.

Minguillón, M. C., Pérez, N., Marchand, N., Bertrand, A., TemimeRoussel, B., Agrios, K., Szidat, S., van Drooge, B. L., Sylvestre, A., Alastuey, A., Reche, C., Ripoll, A., Marco, E., Grimalt, J. O., and Querol, X.: Secondary organic aerosol origin in an urban environment. Influence of biogenic and fuel combustion precursors, Faraday Discuss., 189, 337-359, 2016.

Mohr, C., Thornton, J. A., Heitto, A., Lopez-Hilfiker, F. D., Lutz, A., Riipinen, I., Hong, J., Donahue, N. M., Hallquist, M., Petäjä, T., Kulmala, M., and Yli-Juuti, T.: Molecular identification of organic vapors driving atmospheric nanoparticle growth, Nat. Commun., 10, 1-7, https://doi.org/10.1038/s41467-019-124732, 2019.

Møller, K. H., Tram, C. M., and Kjaergaard, H. G.: Side-by-Side Comparison of Hydroperoxide and Corresponding Alcohol as Hydrogen-Bond Donors, J. Phys. Chem. A, 121, 2951-2959, https://doi.org/10.1021/acs.jpca.7b01323, 2017.

Molteni, U., Bianchi, F., Klein, F., El Haddad, I., Frege, C., Rossi, M. J., Dommen, J., and Baltensperger, U.: Formation of highly oxygenated organic molecules from aromatic compounds, Atmos. Chem. Phys., 18, 1909-1921, https://doi.org/10.5194/acp18-1909-2018, 2018.

Ng, N. L., Herndon, S. C., Trimborn, A., Canagaratna, M. R., Croteau, P. L., Onasch, T. B., Sueper, D., Worsnop, D. R., Zhang, Q., Sun, Y. L., and Jayne, J. T.: An Aerosol Chemical Speciation Monitor (ACSM) for routine monitoring of the composition and mass concentrations of ambient aerosol, Aerosol Sci. Tech., 45, 770-784, https://doi.org/10.1080/02786826.2011.560211, 2011.

Nieminen, T., Lehtinen, K. E. J., and Kulmala, M.: Sub-10 nm particle growth by vapor condensation - effects of vapor molecule size and particle thermal speed, Atmos. Chem. Phys., 10, 9773 9779, https://doi.org/10.5194/acp-10-9773-2010, 2010.

Olenius, T., Halonen, R., Kurtén, T., Henschel, H., KupiainenMäättä, O., Ortega, I. K., Jen, C. N., Vehkamäki, H., and Riipinen, I.: New particle formation from sulfuric acid and amines: Comparison of monomethylamine, dimethylamine, and trimethylamine, J. Geophys. Res., 122, 7103-7118, https://doi.org/10.1002/2017JD026501, 2017.

Olin, M., Kuuluvainen, H., Aurela, M., Kalliokoski, J., Kuittinen, N., Isotalo, M., Timonen, H. J., Niemi, J. V., Rönkkö, T., and Dal Maso, M.: Traffic-originated nanocluster emission exceeds $\mathrm{H}_{2} \mathrm{SO}_{4}$-driven photochemical new particle formation in an urban area, Atmos. Chem. Phys., 20, 1-13, https://doi.org/10.5194/acp20-1-2020, 2020.

Ortega, I. K., Kupiainen, O., Kurtén, T., Olenius, T., Wilkman, O., McGrath, M. J., Loukonen, V., and Vehkamäki, H.: From quantum chemical formation free energies to evaporation rates, Atmos. Chem. Phys., 12, 225-235, https://doi.org/10.5194/acp-12225-2012, 2012.

Ortega, I. K., Olenius, T., Kupiainen-Määttä, O., Loukonen, V., Kurtén, T., and Vehkamäki, H.: Electrical charging changes the composition of sulfuric acidammonia/dimethylamine clusters, Atmos. Chem. Phys., 14, 7995-8007, https://doi.org/10.5194/acp-14-7995-2014, 2014.

Paasonen, P., Olenius, T., Kupiainen, O., Kurtén, T., Petäjä, T., Birmili, W., Hamed, A., Hu, M., Huey, L. G., Plass-Duelmer, C., Smith, J. N., Wiedensohler, A., Loukonen, V., McGrath, M. J., Ortega, I. K., Laaksonen, A., Vehkamäki, H., Kerminen, V.-M., and Kulmala, M.: On the formation of sulphuric acid - amine clusters in varying atmospheric conditions and its influence on atmospheric new particle formation, Atmos. Chem. Phys., 12, 9113-9133, https://doi.org/10.5194/acp-12-9113-2012, 2012.

Pandolfi, M., Amato, F., Reche, C., Alastuey, A., Otjes, R. P., Blom, M. J., and Querol, X.: Summer ammonia measurements in a densely populated Mediterranean city, Atmos. Chem. Phys., 12, 7557-7575, https://doi.org/10.5194/acp-12-7557-2012, 2012.

Passananti, M., Zapadinsky, E., Zanca, T., Kangasluoma, J., Myllys, N., Rissanen, M. P., Kurtén, T., Ehn, M., Attoui, M., and Vehkamäki, H.: How well can we predict cluster fragmentation inside a mass spectrometer?, Chem. Commun., 55, 5946-5949, https://doi.org/10.1039/c9cc02896j, 2019.

Penner, J. E., Xu, L., and Wang, M.: Satellite methods underestimate indirect climate forcing by aerosols, P. Natl. Acad. Sci. USA, 108, 13404-13408, https://doi.org/10.1073/pnas.1018526108, 2011.

Praske, E., Otkjær, R. V., Crounse, J. D., Hethcox, J. C., Stoltz, B. M., Kjaergaard, H. G., and Wennberg, P. O.: Atmospheric autoxidation is increasingly important in urban and suburban North America, P. Natl. Acad. Sci. USA, 115, 64-69, https://doi.org/10.1073/pnas.1715540115, 2018.

Quéléver, L. L. J., Kristensen, K., Normann Jensen, L., Rosati, B., Teiwes, R., Daellenbach, K. R., Peräkylä, O., Roldin, P., Bossi, R., Pedersen, H. B., Glasius, M., Bilde, M., and Ehn, M.: Effect of temperature on the formation of highly oxygenated organic molecules (HOMs) from alpha-pinene ozonolysis, At- 
mos. Chem. Phys., 19, 7609-7625, https://doi.org/10.5194/acp19-7609-2019, 2019.

Querol, X., Gangoiti, G., Mantilla, E., Alastuey, A., Minguillón, M. C., Amato, F., Reche, C., Viana, M., Moreno, T., Karanasiou, A., Rivas, I., Pérez, N., Ripoll, A., Brines, M., Ealo, M., Pandolfi, M., Lee, H.-K., Eun, H.-R., Park, Y.-H., Escudero, M., Beddows, D., Harrison, R. M., Bertrand, A., Marchand, N., Lyasota, A., Codina, B., Olid, M., Udina, M., Jiménez-Esteve, B., Soler, M. R., Alonso, L., Millán, M., and Ahn, K.-H.: Phenomenology of high-ozone episodes in NE Spain, Atmos. Chem. Phys., 17, 2817-2838, https://doi.org/10.5194/acp-17-2817-2017, 2017.

Reche, C., Viana, M., Karanasiou, A., Cusack, M., Alastuey, A., Artiñano, B., Revuelta, M. A., López-Mahía, P., BlancoHeras, G., Rodríguez, S., Sánchez de la Campa, A. M., Fernández-Camacho, R., González-Castanedo, Y., Mantilla, E., Tang, Y. S., and Querol, X.: Urban $\mathrm{NH}_{3}$ levels and sources in six major Spanish cities, Chemosphere, 119, 769-777, https://doi.org/10.1016/j.chemosphere.2014.07.097, 2015.

Riccobono, F., Schobesberger, S., Scott, C., Dommen, J., Ortega, I., Rondo, L., Almeida, J., Amorim, A., Bianchi, F., Breitenlechner, M., David, A., Downard, A., Dunne, E., Duplissy, J., Ehrhart, S., Flagan, R., Franchin, A., Hansel, A., Junninen, H., Kajos, M., Keskinen, H., Kupc, A., Kürten, A., Kvashin, A., Laaksonen, A., Lehtipalo, K., Makhmutov, V., Mathot, S., Nieminen, T., Onnela, A., Petäjä, T., Praplan, A., Santos, F., Schallhart, S., Seinfeld, J., Sipilä, M., Van Spracklen, D., Stozhkov, Y., Stratmann, F., Tomé, A., Tsagkogeorgas, G., Vaattovaara, P., Viisanen, Y., Vrtala, A., Wagner, P., Weingartner, E., Wex, H., Wimmer, D., Carslaw, K., Curtius, J., Donahue, N., Kirkby, J., Kulmala, M., Worsnop, D., and Baltensperger, U.: Oxidation products of biogenic emissions contribute to nucleation of atmospheric particles, Science, 344, 717-721, https://doi.org/10.1126/science.1243527, 2014.

Rissanen, M. P.: $\mathrm{NO}_{2}$ Suppression of AutoxidationInhibition of Gas-Phase Highly Oxidized Dimer Product Formation, ACS Earth Space Chem., 2, 1211-1219, https://doi.org/10.1021/acsearthspacechem.8b00123, 2018.

Rose, C., Zha, Q., Dada, L., Yan, C., Lehtipalo, K., Junninen, H., Mazon, S. B., Jokinen, T., Sarnela, N., Sipilä, M., Petäjä, T., Kerminen, V.-M., Bianchi, F., and Kulmala, M.: Observations of biogenic ion-induced cluster formation in the atmosphere, Sci. Adv., 4, 5218, https://doi.org/10.1126/sciadv.aar5218, 2018.

Schervish, M. and Donahue, N. M.: Peroxy radical chemistry and the volatility basis set, Atmos. Chem. Phys., 20, 1183-1199, https://doi.org/10.5194/acp-20-1183-2020, 2020.

Schobesberger, S., Junninen, H., Bianchi, F., Lönn, G., Ehn, M., Lehtipalo, K., Dommen, J., Ehrhart, S., Ortega, I. K., Franchin, A., Nieminen, T., Riccobono, F., Hutterli, M., Duplissy, J., Almeida, J., Amorim, A., Breitenlechner, M., Downard, A. J., Dunne, E. M., Flagan, R. C., Kajos, M., Keskinen, H., Kirkby, J., Kupc, A., Kürten, A., Kurtén, T., Laaksonen, A., Mathot, S., Onnela, A., Praplan, A. P., Rondo, L., Santos, F. D., Schallhart, S., Schnitzhofer, R., Sipilä, M., Tomé, A., Tsagkogeorgas, G., Vehkamäki, H., Wimmer, D., Baltensperger, U., Carslaw, K. S., Curtius, J., Hansel, A., Petäjä, T., Kulmala, M., Donahue, N. M., and Worsnop, D. R.: Molecular understanding of atmospheric particle formation from sulphuric acid and large oxidized organic molecules, P. Natl. Acad. Sci. USA, 110, 17223-17228, https://doi.org/10.1073/pnas.1306973110, 2013.
Simon, M., Heinritzi, M., Herzog, S., Leiminger, M., Bianchi, F., Praplan, A., Dommen, J., Curtius, J., and Kürten, A.: Detection of dimethylamine in the low pptv range using nitrate chemical ionization atmospheric pressure interface time-of-flight (CI-APiTOF) mass spectrometry, Atmos. Meas. Tech., 9, 2135-2145, https://doi.org/10.5194/amt-9-2135-2016, 2016.

Sipilä, M., Sarnela, N., Jokinen, T., Henschel, H., Junninen, H., Kontkanen, J., Richters, S., Kangasluoma, J., Franchin, A., Peräkylä, O., Rissanen, M. P., Ehn, M., Vehkamäki, H., Kürten, T., Berndt, T., Petäjä, T., Worsnop, D., Ceburnis, D., Kerminen, V. M., Kulmala, M., and O’Dowd, C.: Molecular-scale evidence of aerosol particle formation via sequential addition of $\mathrm{HIO}_{3}$, Nature, 537, 532-534, https://doi.org/10.1038/nature19314, 2016.

Stolzenburg, D., Fischer, L., Vogel, A. L., Heinritzi, M., Schervish, M., Simon, M., Wagner, A. C., Dada, L., Ahonen, L. R., Amorim, A., Baccarini, A., Bauer, P. S., Baumgartner, B., Bergen, A., Bianchi, F., Breitenlechner, M., Brilke, S., Buenrostro Mazon, S., Chen, D., Dias, A., Draper, D. C., Duplissy, J., El Haddad, I., Finkenzeller, H., Frege, C., Fuchs, C., Garmash, O., Gordon, H., He, X., Helm, J., Hofbauer, V., Hoyle, C. R., Kim, C., Kirkby, J., Kontkanen, J., Kürten, A., Lampilahti, J., Lawler, M., Lehtipalo, K., Leiminger, M., Mai, H., Mathot, S., Mentler, B., Molteni, U., Nie, W., Nieminen, T., Nowak, J. B., Ojdanic, A., Onnela, A., Passananti, M., Petäjä, T., Quéléver, L. L. J., Rissanen, M. P., Sarnela, N., Schallhart, S., Tauber, C., Tomé, A., Wagner, R., Wang, M., Weitz, L., Wimmer, D., Xiao, M., Yan, C., Ye, P., Zha, Q., Baltensperger, U., Curtius, J., Dommen, J., Flagan, R. C., Kulmala, M., Smith, J. N., Worsnop, D. R., Hansel, A., Donahue, N. M., and Winkler, P. M.: Rapid growth of organic aerosol nanoparticles over a wide tropospheric temperature range, P. Natl. Acad. Sci. USA, 115, 9122-9127, 2018.

Tröstl, J., Chuang, W. K., Gordon, H., Heinritzi, M., Yan, C., Molteni, U., Ahlm, L., Frege, C., Bianchi, F., Wagner, R., Simon, M., Lehtipalo, K., Williamson, C., Craven, J. S., Duplissy, J., Adamov, A., Almeida, J., Bernhammer, A. K., Breitenlechner, M., Brilke, S., Dias, A., Ehrhart, S., Flagan, R. C., Franchin, A., Fuchs, C., Guida, R., Gysel, M., Hansel, A., Hoyle, C. R., Jokinen, T., Junninen, H., Kangasluoma, J., Keskinen, H., Kim, J., Krapf, M., Kürten, A., Laaksonen, A., Lawler, M., Leiminger, M., Mathot, S., Möhler, O., Nieminen, T., Onnela, A., Petäjä, T., Piel, F. M., Miettinen, P., Rissanen, M. P., Rondo, L., Sarnela, N., Schobesberger, S., Sengupta, K., Sipilä, M., Smith, J. N., Steiner, G., Tomè, A., Virtanen, A., Wagner, A. C., Weingartner, E., Wimmer, D., Winkler, P. M., Ye, P., Carslaw, K. S., Curtius, J., Dommen, J., Kirkby, J., Kulmala, M., Riipinen, I., Worsnop, D. R., Donahue, N. M., and Baltensperger, U.: The role of low-volatility organic compounds in initial particle growth in the atmosphere, Nature, 533, 527-531, https://doi.org/10.1038/nature18271, 2016.

Van Damme, M., Clarisse, L., Whitburn, S., Hadji-Lazaro, J., Hurtmans, D., Clerbaux, C., and Coheur, P. F.: Industrial and agricultural ammonia point sources exposed, Nature, 564, 99-103, https://doi.org/10.1038/s41586-018-0747-1, 2018.

Wang, S., Wu, R., Berndt, T., Ehn, M., and Wang, L.: Formation of Highly Oxidized Radicals and Multifunctional Products from the Atmospheric Oxidation of Alkylbenzenes, Environ. Sci. Technol., 51, 8442-8449, https://doi.org/10.1021/acs.est.7b02374, 2017. 
Yan, C., Nie, W., Äijälä, M., Rissanen, M. P., Canagaratna, M. R., Massoli, P., Junninen, H., Jokinen, T., Sarnela, N., Häme, S. A. K., Schobesberger, S., Canonaco, F., Yao, L., Prévôt, A. S. H., Petäjä, T., Kulmala, M., Sipilä, M., Worsnop, D. R., and Ehn, M.: Source characterization of highly oxidized multifunctional compounds in a boreal forest environment using positive matrix factorization, Atmos. Chem. Phys., 16, 12715-12731, https://doi.org/10.5194/acp-16-12715-2016, 2016.

Yan, C., Dada, L., Rose, C., Jokinen, T., Nie, W., Schobesberger, S., Junninen, H., Lehtipalo, K., Sarnela, N., Makkonen, U., Garmash, O., Wang, Y., Zha, Q., Paasonen, P., Bianchi, F., Sipilä, M., Ehn, M., Petäjä, T., Kerminen, V.-M., Worsnop, D. R., and Kulmala, M.: The role of $\mathrm{H}_{2} \mathrm{SO}_{4}-\mathrm{NH}_{3}$ anion clusters in ion-induced aerosol nucleation mechanisms in the boreal forest, Atmos. Chem. Phys., 18, 13231-13243, https://doi.org/10.5194/acp-1813231-2018, 2018.

Yan, C., Nie, W., Vogel, A. L., Dada, L., Lehtipalo, K., Stolzenburg, D., Wagner, R., Rissanen, M. P., Xiao, M., Ahonen, L., Fischer, L., Rose, C., Bianchi, F., Gordon, H., Simon, M., Heinritzi, M., Garmash, O., Roldin, P., Dias, A., Ye, P., Hofbauer, V., Amorim, A., Bauer, P. S., Bergen, A., Bernhammer, A.-K., Breitenlechner, M., Brilke, S., Buchholz, A., Mazon, S. B., Canagaratna, M. R., Chen, X., Ding, A., Dommen, J., Draper, D. C., Duplissy, J., Frege, C., Heyn, C., Guida, R., Hakala, J., Heikkinen, L., Hoyle, C. R., Jokinen, T., Kangasluoma, J., Kirkby, J., Kontkanen, J., Kürten, A., Lawler, M. J., Mai, H., Mathot, S., Mauldin, R. L., Molteni, U., Nichman, L., Nieminen, T., Nowak, J., Ojdanic, A., Onnela, A., Pajunoja, A., Petäjä, T., Piel, F., Quéléver, L. L. J., Sarnela, N., Schallhart, S., Sengupta, K., Sipilä, M., Tomé, A., Tröstl, J., Väisänen, O., Wagner, A. C., Ylisirniö, A., Zha, Q., Baltensperger, U., Carslaw, K. S., Curtius, J., Flagan, R. C., Hansel, A., Riipinen, I., Smith, J. N., Virtanen, A., Winkler, P. M., Donahue, N. M., Kerminen, V.-M., Kulmala, M., Ehn, M., and Worsnop, D. R.: Size-dependent influence of $\mathrm{NO}_{x}$ on the growth rates of organic aerosol particles, Sci. Adv., 6, eaay4945, https://doi.org/10.1126/sciadv.aay4945, 2020.
Yao, L., Garmash, O., Bianchi, F., Zheng, J., Yan, C., Kontkanen, J., Junninen, H., Mazon, S. B., Ehn, M., Paasonen, P., Sipilä, M., Wang, M., Wang, X., Xiao, S., Chen, H., Lu, Y., Zhang, B., Wang, D., Fu, Q., Geng, F., Li, L., Wang, H., Qiao, L., Yang, X., Chen, J., Kerminen, V. M., Petäjä, T., Worsnop, D. R., Kulmala, M., and Wang, L.: Atmospheric new particle formation from sulphuric acid and amines in a Chinese megacity, Science, 361, 278-281, https://doi.org/10.1126/science.aao4839, 2018.

Yli-Juuti, T., Pajunoja, A., Tikkanen, O. P., Buchholz, A., Faiola, C., Väisänen, O., Hao, L., Kari, E., Peräkylä, O., Garmash, O., Shiraiwa, M., Ehn, M., Lehtinen, K., and Virtanen, A.: Factors controlling the evaporation of secondary organic aerosol from $\alpha$-pinene ozonolysis, Geophys. Res. Lett., 44, 2562-2570, https://doi.org/10.1002/2016GL072364, 2017.

Yu, H., Zhou, L., Dai, L., Shen, W., Dai, W., Zheng, J., Ma, Y., and Chen, M.: Nucleation and growth of sub-3 nm particles in the polluted urban atmosphere of a megacity in China, Atmos. Chem. Phys., 16, 2641-2657, https://doi.org/10.5194/acp16-2641-2016, 2016.

Zhang, R., Khalizov, A., Wang, L., Hu, M., and Xu, W.: Nucleation and growth of nanoparticles in the atmosphere, Chem. Rev., 112, 1957-2011, https://doi.org/10.1021/cr2001756, 2012.

Zhao, J., Eisele, F. L., Titcombe, M., Kuang, C., and McMurry, P. H.: Chemical ionization mass spectrometric measurements of atmospheric neutral clusters using the cluster-CIMS, J. Geophys. Res., 115, 1-19, https://doi.org/10.1029/2009jd012606, 2010. 